\title{
Abstracts of the ASHS Southern Region 54th Annual Meeting
}

\section{National Sweetpotato Collaborators}

WEED CONTROL IN SWEET POTATOES WITH METOLACHLOR Wayne C. Porter', Louisiana State University Agricultural Center, Louisiana Agricultural Experiment Station, Hammond Research Station, Hammond, LA 70403

Studies were conducted to evaluate metolachlor for weed control and crop tolerance in sweet potatoes. Metolachlor was applied posttransplant at rates of $0.5,1.0$, or $2.01 \mathrm{~b} / \mathrm{A}$. Tank-mix combinations of metolachlor + clomazone were also evaluated. Clomazone was the standard herbicide used for comparison. Metolachlor alone or in combination with clomazone did not cause any serious reduction in sweet potato plant vigor when applied posttransplant. Metolachlor provided excellent control of Brachiaria platyphylla, Cyperus iria, Cyperus esculentus, and Amaranthus hybridus. Tank-mixes with clomazone did not improve the weed control of metolachlor alone. Yields of No. 1 and marketable roots from metolachlortreated plots were equal to or greater than yields from plots treated with clomazone.

RESISTANCE IN SWEETPOTATO TO ROOT-KNOT NEMATODE: ITS VALUE AND OTHER BENEFITS

P. D. Dukes* and J. R. Bohac, USDA-ARS, U. S. Vegetable Lab., Charleston, SC 29414, and J. D. Mueller, Clemson University, Edisto Research and Education Center, Blackville, SC 29817

A root-knot nematode (Meloldogyne incognita) project was initiated in a field of infested sandy loam (EREC) in 1991 and continued. There were ten sweetpotato entries consisting of six cultivars (Beauregard. Excel, Georgia Jet, Jewel, Red Jewel, and Sumor), three advanced lines (W-270, W-274, and W-279) and PI 399161 which were selected for their diversity in disease reactions and other traits. Each entry was planted in the same plots each year to monitor effects of continuous cropping, disease reactions, yield and population shifts of the pathogen. Marketable yields were reduced each year for Georgia Jet and Red Jewel, but not for Beauregard. Internal necrosis in the storage roots was most severe for Beauregard. Several of the highly resistant entries, especially Sumor and W-279, performed well each year, including high yields, good quality. and little or no nematode reproduction. This study demonstrates the considerable economic benefits of a high level of durable resistance to root knot in sweetpotato.

THE EFFECT OF PLANT SPACING ON SWEET POTATO VARIETIES AND PROMISING SEEDLINGS

W.A. Mulkey*, W.B. McLemore, III and T.P. Talbot, Louisiana State University Agricultural Center, Sweet Potato Research Station, Chase,-LA-71324

In-row spacing studies have been conducted with

'Beauregard!, 'Hernandez' and some promising seedlings in the LSU Agricultural Center sweet potato breeding program. May, June and early July plantings are evaluated on $1 \mathrm{~m}$ rows with in-row spacings of $23,30,38$, and $46 \mathrm{~cm}$. With the variety 'Beauregard' early May plantings (1-15th) yields of U.S. No.1 grade roots are higher at the $30 \mathrm{~cm}$ spacing. From mid-May to
June 20th higher yields of No. 1's are produced at a $23 \mathrm{~cm}$ spacing. Higher yields are obtained in the late June-early July plantings at the $30 \mathrm{~cm}$ spacing. Highest yields overall are produced in late May-early June plantings with 'Beauregard'. With the 'Hernandez' variety the highest yield of U.S. No.1 grade roots have been produced at a $38 \mathrm{~cm}$ in-row spacing during all three planting seasons, with the highest yields overall being produced in the May plantings. Days to maturity are reduced in early 'Hernandez' plantings. Results of limited in-row plant spacing with the seedling 'LU7-59' are identical to the 'Beauregard' variety.

NITROGEN FERTILIZATION OF SWEET POTATO AND ITS EFFECT ON HOOT SET AND YIELD

W.A. Mulkey*, W.B. McLemore, III and T.P. Talbot, Louisiana State University Agricultural Center, Sweet Potato Research Station, Chase,-LA- 71324

In preplant nitrogen studies with the 'Beauregard' Variety maximum yields of U.S. No. 1 grade roots are produced using $50.4 \mathrm{~kg} / \mathrm{ha} \mathrm{N}$. In 1992 studies were initiated to determine the effect of preplant $\mathrm{N}$ rates on storage root set and yield. Preplant $\mathrm{N}$ rates ranged from 0 to $84 \mathrm{~kg} / \mathrm{ha}$ in $16.8 \mathrm{~kg} /$ ha increments. Two plots each of $0,16.8$ and $33.6 \mathrm{~kg} / \mathrm{ha}$ were included so sidedress applications could be made to bring one of the treatments to the $50.4 \mathrm{~kg} / \mathrm{ha} \mathrm{N}$ level 30 days after transplanting. The $0 \mathrm{~kg} / \mathrm{ha} \mathrm{N}$ treatment had significantly more storage roots per plant than all other treatments 21 days after transplanting and more vine growth measured by weight. The 0 and $16.8 \mathrm{~kg} / \mathrm{ha}$ treatments had significantly more storage roots 26 days after transplanting. At 26 and 35 days after transplanting vine growth was greater in $16.8 \mathrm{~kg} / \mathrm{ha} \mathrm{N}$ treatment. The 0 plus $50.4 \mathrm{~kg} / \mathrm{ha} \mathrm{N}$ sidedress treatment produced the highest yield of U.S. No. 1 grade roots with the highest number of marketable roots per plant (5.0). Similar results were obtained in the 1993 studies.

\section{BREEDING FOR INSECT RESISTANCE IN SWEETPOTATO}

J.R. Bohac*. J. M. Schalk, P.D. Dukes, U.S. Vegetable Laboratory, Charleston, SC and W.R. Martin, Biosys Palo Alto, CA.

A two year study was conducted to evaluate the efficacy of insect resistance in sweetpotato cultivars from our breeding program in combination with an insecticide (fonofos) and/or a parasitic nematode (Steinernema carpocapsae). In the laboratory, use of the parasitic nematode resulted in $99 \%$ mortality of Diabrotica larvae. In both years, much higher control of damage by all insect classes was achieved by the use of resistant cultivars in combination with a nematode and/or fonofos treatment. Analysis of the first year's field data showed the parasitic nematode treatment gave good damage protection against the WDS (Wireworm, Diabrotica, Systena), sweetpotato flea beetle, but not grubs. In this same year, fonofos only gave good protection against WDS. In the second test year, fonofos gave good protection against WDS, but the nematode did not. High moisture conditions may have affected the efficacy of the parasitic nematode. Host plant resistance by sweetpotato cultivars appears to be less affected by variable field conditions and accounted for $64 \%$ of the total crop protection (compared to the check susceptible line). 
YIELD DIFFERENCES AND DNA POLYMORPHISMS WITHIN SWEETPOTATO cv. 'JEWEL' CLONES

Arthur Q. Villordon* and Don R. LaBonte, Dept. of Horticulture, LSU Agricultural Center, Baton Rouge, LA 70803

Clonal propagation assures the maintenance of genetic purity of a sweetpotato variety. The existence of foundation seed programs further contributes to the conservation of favorable genetic constitution in a commercial cultivar. However, the improvement of current maintenance procedures is necessary as shown by the occurrence of mutations and the decline of certain commercial varieties. Information on the nature and extent of changes in sweetpotato would therefore be useful in this regard. 'Jewel' clones obtained from eight state foundation seed programs were subjected to yield tests and a RAPD-based assay. Differences in nearly all yield grades were detected during the 1991, 1992, and 1993 seasons. The yield of U.S. No. 1 grade roots varied from $27 \%$ to $46 \%$. The quality factors measured also varied: $\%$ alcohol insoluble solids varied by $13 \%$, while sucrose ranged from $9.6 \%$ to $19 \%$. Total DNA was extracted from each clone and assayed against 40 primers. All primers produced amplified fragments. A total of 110 reproducible bands was generated by 38 primers. Putative polymorphic markers were scored in 21 $(18.58 \%)$ of these bands based on the presence or absence of amplified products. The results suggest an underlying cause for the variability observed in phenotypic traits within sweetpotato clones.

SWEETPOTATO STORAGE ROOT MUTATIONS

R. C. Sloan, Jr.*, P. G. Thompson, W. B. Burdine, Jr., J. L. Main, P. D. Gerard, Department of Plant and Soil Sciences, Mississippi State, MS 39762.

'Beauregard' storage roots which were discarded from the Mississippi sweetpotato foundation seed program because of the presence of flesh mutations were bedded in Spring 1991. After the plants were pulled from the roots, the roots were further examined, and the flesh mutations were characterized by size and frequency. The progency from the original roots were examined for flesh mutations for three generations in 1991, 1992, and 1993. The degree of mutation in the original root did not influence the degree of mutation in succeeding generations of storage roots. In 1992 and 1993, the degree of mutation in the third and fourth generation roots did not differ from that of storage roots grown from plants from the foundation seed plant beds.

DNA SEQUENCE POLYMORPHISM BASED GENETIC DIVERSITY STUDIES IN SWEETPOTATO GERMPLASM Channapatna S. Prakash*, Guohan He, and Robert_L__Jarret ${ }^{1}$, 'USDA/ARS, Reg. Plant Introd. Station, Griffin, GA 30223.

Highly polymorphic DNA markers were identified in sweetpotato (Ipomoea batatas) using PCR amplification and arbitrary primers. More than 100 accessions representing US cultivars and their progenitors, and germplasm lines from around the world were analyzed. Sweetpotato germplasm exhibited high genetic variability and individual-specific profiles were obtained for all accessions. US cultivars formed a tight cluster in the principal coordinate analysis suggesting a narrow genetic base. The genetic relationship data of US cultivars and their progenitors based on DNA polymorphisms was in agreement with their known pedigree. The putative paternal parents of certain cultivars selected through open pollination were identified based on shared polymorphisms. The PCR-based markers are valuable in the characterization of sweetpotato germplasm and in ensuring a broad genetic base for future cultivars.

\section{GENETIC LINKAGES OF RAPD MARKERS IN SWEETPOTATO}

Liang L. Hong* and Paul G. Thompson, Plant and Soil Sciences Department, Mississippi State University, Mississippi State, MS 39762 Random amplified polymorphic DNA (RAPD) markers were analyzed in parents and progeny of four sweetpotato crosses. An average of 69 primers were tested and $23.5 \%$ produced well resolved polymorphic banding patterns. Each polymorphic primer had an average of 1.9 polymorphic bands resulting in 0.45 polymorphic fragments per primer tested. Phenotypic segregation ratios of $88 \%$ of polymorphic fragments fit those expected for hexaploid Mendelian inheritance.
Numbers of linked polymorphic fragments and numbers of linkage groups were 13 and 5 for Cross A, 0 and 0 for Cross B, 23 and 3 for Cross C and 16 and 6 for Cross D. Those results indicated that RAPD markers have potential for a genetic linkage map in sweetpotato; however, many primers must be screened.

GENETIC CORRELATION BETWEEN RESISTANCE TO SWEETPOTATO WEEVIL AND OTHER INSECTS

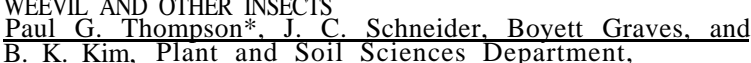
Mississpi State University, 39762

Twenty-four half-sib sweetpotato families were field tested for freedom from injury by sweetpotato weevil and other soil inhabiting, injurious insects (WDS). Three pairs of adult male and female weevils were applied to the crown of each plant at the beginning of storage root enlargement. Naturally occurring numbers of WDS were high enough for considerable injury from those insects. WDS injury free roots ranged from $19 \%$ in Centennial, the suceptible control, to 57\% in Regal, the resistant control. The highest family mean for percent non-injured by WDS was $55 \%$. Weevil injury free roots ranged from $67 \%$ in Centennial to $90 \%$ in Regal with 3 families producing mean weevil non-injured roots of $89 \%$. The genetic correlation between weevil injury free and WDS injury free roots was $0.69 \pm 0.28$. That estimate is preliminary and based on data from one environment. Evaluations will be repeated in 1994 for estimates of GXE to derive genetic correlation estimates with less environmental interactions.

VIRUS-FREE MICROPROPAGATED PLANTS AND CLONE EFFECTS ON SWEETPOTATO YIELD, 1993

Jonathan R. Schultheis*

Department of Horticultural Science, North Carolina State University, Raleigh, NC 27695-7609

Commercially grown sweetpotato contain virus. Hill selection is practiced to maintain quality and trueness to type of a variety. Three field plantings of Beauregard and Jewel were made in 1993 to compare the yield of virus-free planting stock obtained from micropropagared plants (VFM); virusinfected planting stock obtained from micropropagated plants (VIM); foundation, registered, grower seed stock; and a selected California Jewel clone in which the virus was removed, then micropropagated (CVFM). For Beauregard, VFM had significantly more yield of marketable and number 1 roots at the 0.06 level of significance than plants not micropropagated. The yield of number 1 roots was also greater with VFM compared with VIM. Marketable yields of Beauregard were superior when registered versus grower seed (nor in certification program) were compared. For Jewel, marketable yields were increased from VFM versus plants not micropropagated. VFM and the VIM yielded similarly as did registered and grower seed stock. The VFM Jewel clone from North Carolina outyielded CVFM. Yield was at least as good when obtained from VFM compared with the other planting stocks. A yield increase of 10 to $20 \%$ was common when using VFM, hill selected sweetpotatoes.

RUSSET CRACK-LIKE SYMPTOMS IN BEAUREGARD SWEETPOTATO REDUCED BY VIRUS INDEXING AND MICROPROPAGATION W. R.(Bill) Jester*, Charles W. Averre and Jonathan R. Schultheis North Carolina Cooperative Extension Service, Plant Pathology, Department of Horticultural Science, North Carolina State University, Raleigh, NC 27695

Russet crack-like symptoms have been observed with increasing frequency on Beauregard storage roots in North Carolina and resulted in some crop failures in neighboring states. The objective of this experiment was to determine if this cracking disorder was soil-borne, seed transmissible or transmissible via grafting. Beauregard plants were obtained from cuttings from commercially available virus-indexed micropropagated plants (M), and selected symptomatic roots (culls) originating from 1992 Foundation stocks (R). In a third treatment plants from each source were alternated in a row, then $\mathrm{M}$ and $\mathrm{R}$ plants were cleft grafted. The planting was made June 30, 1993 and replicated five times (12 plants per rep). Yield was determined and roots from each hill were washed and examined for russet crack-like symptom(s), and interior color on the proximal end. M roots had $82 \%$ good color; while R roots had $19 \%$. $\mathrm{M}$ plants contained $0.3 \%$ symptomatic roots; R plants $65.5 \%$. Similarly, only $1.6 \%$ of the M plants contained a symptomatic root, while $95.0 \%$ of the $\mathrm{R}$ plants had symptomatic roots. One-third of the grafted M plants contained one or more roots with cracking symptoms. M outyielded R. The russet crack-like disorder was determined to not be soil-borne, but was transmissible through the seed or grafting. 


\section{Vigna Crop Advisory Committee}

EVALUATION OF VIGNA UNGUICULATA GERMPLASM FOR RESISTANCE TO MOSAIC VIRUSES

Oyette L. Chambliss*. Arthur G. Hunter, Department of Horticulture, Auburn University. AL 36849-5408 and Richard O. Hampton, USDA, ARS, Department of Botany and Plant Pathology, Oregon State University, Corvallis, OR 97331-2902

Germplasm accessions and advanced lines were evaluated for seed transmission of the seed borne viruses, cucumber mosaic (CMV), cowpea severe mosaic (CSMV), and blackeye cowpea mosaic (B1CMV). Seed samples from 822 field plots (274 out of 300 accessions in 3 replications) which had been evaluated for insect resistance in 1992 were planted in the greenhouse. Mosaic virus symptoms had been apparen throughout the 1992 field planting. Evaluation for mosaic symptoms was done at the seedling stage in the greenhouse and 89 entries exhibited seed borne virus symptoms in one or more plants. Of these, 78 were shown by ELISA (enzyme linked immunosorbant assay, direct antigen coating method) to contain at least one of the seed borne viruses for which we were evaluating.

\section{National Cowpea Improvement Assn.}

PROPOSED METHODOLOGY FOR BREEDING SOUTHERNPEA CULTIVARS WITH PERSISTENT GREEN SEED COLOR

R. L. Fery* and P. D. Dukes, U.S. Vegetable Laboratory, ARS, USDA, 2875 Savannah Highway, Charleston, SC 29414-5334

The results of recently completed genetic studies indicate that the green cotyledon trait exhibited by the southernpea [Vigna unguiculata (L.) Walp.] cultivar

Bettergreen is conditioned by a single recessive gene. This gene, designated green cotyledon and symbolized $\mathrm{gc}$, is neither allelic to nor linked with the gt gene that conditions the green testa trait exhibited by the cultivar Freezegreen. The color of seeds harvested from plants homozygous for both the $\mathrm{gc}$ and $\mathrm{gt}$ genes is superior and more uniform than the color of seeds harvested from either Better-green or Freezegreen plants. This observation suggests that efforts should be initiated to study the feasibility of using both the $\mathrm{gc}$ and $\mathrm{gt}$ genes to develop cultivars that produce seed with an enhanced, persistent green color. The selection methodology for both seed traits is rapid and reliable. The green cotyledon trait can be selected in the seed stage.

SEED-BORNE VIRUSES IN U.S. COWPEA CROPS: A STATUS REPORT AND STRATEGY FOR VIRAL DISEASE CONTROL

Richard O. Hampton, USDA ARS, Department of Botany and Plant Pathology, Oregon State University, Corvallis, OR 97331-2902

Blackeye cowpea mosaic potyvirus is the most easily observable seed-borne virus in cowpeas, but is typically seed-transmitted at lower rates (i.e., 0.1 to $2 \%$ ) than the less conspicuous cowpea severe mosaic comovirus or cucumber mosaic cucumovirus. All three viruses are readily vector transmissible after seed-borne inoculum reaches the field, perpetuating and spreading the viruses. Individually and particularly in mixtures, these viruses are capable of decreasing both seed quality and yield. Disease-tolerant cultivars are available, but fail to control viral diseases. Development of superior new cowpea cultivars with multiple viral-disease resistance is clearly within reach and has become essential to long-term, sustainable, profitable cowpea production. This breeding objective requires public-research supported efforts by the combined cowpea seed and processing industries. Southern bean mosaic sobemovirus is also recognized as an important cowpea pathogen, but was encountered at a much lower frequency than the above three viruses in both plant and seed samples, in 1992 and 1993.

\section{J.B. Edmond Undergraduate}

NIGHT TEMPERATURE RESPONSE CURVES FOR IN VITRO POLLEN GERMINATION, POLLEN CHARACTISTICS AND FRUITSET IN TOMATO

Michael Bartholomew* and Mary M. Peet, Department of Horticultural Science, North Carolina State University, Raleigh, NC 27695-7609.

Previous greenhouse studies in Raleigh have shown that nighttime cooling increases tomato fruit weights from $11 \%$ to $53 \%$, depending on planting dates. The physiological mechanism was unclear, except that temperatures during fruitset were most critical We report here on a phytotron experiment comparing pollen characteristics and in vitro pollen germination of plants grown at night temperatures of $18,22,24$ or $26^{\circ} \mathrm{C}$ in a 12 -hour photoperiod with $26^{\circ} \mathrm{C}$ day temperature in all treatments. There was considerable variability between sampling dates in pollen characteristics and \% germination. The most consistent and significant effects were a decrease in total pollen and an increase in \% abnormal pollen at high night temperatures. Number of seed present in the fruit also decreased with increasing night temperatures, indicating that the changes in pollen characteristics adversely affected seedset. Night temperatures of $22 \mathrm{C}$ appeared optimal for many of the pollen and growth characteristics measured, but fruit developed most rapidly at the higher night temperatures

ROLE OF PERLITE IN FLUORIDE TOXICITY OF FLORAL CROPS Tammy L. Everett* and Paul V. Nelson. Dept. of Horticultural Science, North Carolina State University, Raleigh, NC 27695-7609

Five common sources of perlite used in the North American horticultural industry were tested for their release of fluoride during five successive teachings with $\mathrm{pH} 5.2$ sodium phosphate buffer $(1 \mathrm{cc}$ perlite/ml buffer). Soluble fluoride in the first leachate ranged from 0.05 to $0.8 \mathrm{mg} / \mathrm{l}$ and in the fifth leachate from 0.01 to $0.18 \mathrm{mg} / \mathrm{l}$. Lilium Asiatic hybrids 'Pixie Grange' and 'Sunray', Chlorophytum comosum (Thumb.) Jacques 'Variegatum', and Gibasis pellucida (Martens \& Gal.) D. Hunt 'Bridal Veil' were. grown in sphagnum peat moss plus perlite substrates ranging up to $50 \%$ perlite and at substrate $\mathrm{pH}$ levels from 4.6 to 7.0. No fluoride toxicity occurred in these crops in any treatments. The precaution against the use of perlite in substrates used for growing fluoride sensitive crops needs to be reconsidered.

RAPD BANDING PATTERNS IN SWEETPOTATO INFECTED WITH FUSARIUM LATERITIUM

Frank A. Buffone* and Don R. La Bonte, Department of Horticulture, Louisiana State University Agricultural Center, Baton Rouge, LA 70803

Chlorotic Leaf Distortion (CLD) is a common disease of sweetpotato caused by Fusarium lateritium. This fungus is unique among Fusarium species in that it grows on the epidermis of leaves and shoot tips of sweetpotato. Fusarium lateritium appears as a white epiphytic material and under bright sunlight causes leaf chlorosis. When cloudy weather persists for several days, all symptoms disappear.

Researchers who use RAPD to examine banding patterns of sweetpotato DNA assume that foreign DNA present in the cTAB extract is quantitatively low and will not appreciably amplify and appear as bands. In this study we found the modified cTAB procedure used to amplify sweetpotato DNA also amplifies DNA of Fusarium lateritium cultures. DNA banding patterns of infected leaves was compared with those free of the disease. No differences in banding patterns were observed in this preliminary study.

KENAF FIBER CORE MEDIA AND DOLOMITE LEVELS INFLUENCE PLANT GROWTH OF CONTAINER-GROWN GARDEN CHRYSANTHEMUM

Julia L. Lamb*, Jesse R. Quarrels, and Steven E. Newman, Department of Plant and Soil Sciences, Box 9555, Mississippi Agricultural and Forestry Experiment Station, Mississippi State, MS 39762.

Kenaf (Hibiscus cannabinus L.) is a member of the Malvaceae family cultivated primarily for its bast fibers. The objective of this study was to evaluate kenaf fiber core as a substitute for vermiculite in a sphagnum peat moss-based medium. Rooted cuttings of Dendranthema $x$ grandiflora were planted into 1 liter pots containing six sphagnum peat moss-based media modified with fine or coarse, fresh or aged kenaf core and/ or vermiculite. The 
media were (by volume): 5 peat: 5 vermiculite: 0 kenaf, 5 peat: 4 vermiculite1 kenaf; 5 peat: 3 vermiculite: 2 kenaf; 5 peat: 2 vermiculite: 3 kenaf; 5 peat1 vermiculite: 4 kenaf; and 5 peat: 0 vermiculite: 5 kenaf, Dolomite was added at five rates $0,1.5,3,4.5$, and $6 \mathrm{~kg} / \mathrm{m}^{3}$. Gypsum was added to each medium combination to provide equal calcium levels for all treatments. The medium with no kenaf grew the tallest plants. Kenaf that was aged and finely ground produced plants similar in height to controls. Fresh kenaf was detrimental to plant growth. Dolomite ameliorated the fresh kenaf effect slightly.

COTYLEDON AGE VERSUS IN VITRO REGENERATION POTENTIAL IN CUCUMBER (CUCUMIS SATIVUS L.)

Nancy J. Zimmerman* and Nancy A. Reichert, Department of Plant and Soil Sciences, Mississippi State University, Box 9555, Mississippi State, MS 39762

Seed and seedling cotyledon explants from 14 cultivars were placed on 2 media types to induce organogenesis and somatic embryogenesis. Shoots or somatic embryos were counted to determine effects of cultivar, explant and regeneration type on overall regeneration success. Opposite explant preferences were observed for each regeneration type. In somatic embryogenesis, greater numbers of seedling cotyledons were able to respond, while in organogenesis, seed cotyledons responded in greatest numbers. However, within each cultivar, no explant preferences were observed (except in 'Picklebush'). Four cultivars displayed a preference for the somatic embryogenesis regeneration protocol over organogenesis: 'Burpee Hybrid II' and 'Burpless F1 Hybrid' (fresh market types), and 'Cross Country' and 'Picklebush' (pickling types). The best individual regeneration rates were obtained with 'Cross Country' and 'Picklebush' - both for somatic embryogenesis.

\section{Norman F. Childers Graduate}

REMOTE SENSING AS A TOOL IN NATIVE PLANT CONSERVATION Jason Singhurst*, D. L. Creech, and J. Williams. Department of Agriculture, PO Box 13000, Stephen F. Austin State University, Nacogdoches, TX 75962

In Texas, 5,500 native species are distributed over an area comprised of ten regional habitat types. In the Piney Woods region of east Texas, 2,300 plant species occupy 15 million acres. In east Texas, the USFWS has identified 4 species that are federally endangered and 15 that are candidates for that listing. Interest in protecting rare plant habitats and reintroducing those species into similar and appropriate ecosystem types has led to new tools in research and development. Remote sensing is one; this technology is used to derive information about the earth's land and water areas from images acquired at a distance Multispectral and spatial techniques are applied to process and interpret remote sensing imagery for the purpose of producing conventional maps, thematic maps, reource surveys, etc., in the fields of agriculture, botany, archeology, forestry, geography, geology. and others. Remote sensing is used to classify vegetation, interpret forest photogrammetry, estimate timber production, and identify crops, individual plants and leaf structure. This specific project was initiated to determine the potential of remote sensing as a tool to locate known and new rare plant communities in east Texas. To develop benchmark data, a Daedalus scanner image of a previously surveyed and AutoCAD mapped area, the Vista forest on the SFASU campus, was utilized to develop correlations between imagery, vegetation types and species. By inserting various scan images under the Vista forest AutoCAD map, known tree species were analyzed through their specific spectral emission characteristics across nine bands. This pilot project has indicated that it is simple to separate pines from hardwoods and illustrate major land use features. However, separation at the species level or groups of species has not been achieved. This paper will trace the history of this project, describe problems and obstacles encountered, and make recommendations for future strategies.

ARCCAD AS A GIS PLATFORM FOR UNDERSTANDING THE VEGETATION OF STEPHEN F AUSTIN STATE UNIVERSITY

Susan Lindley* and D. L. Creech. Department of Agriculture, PO Box 13000, Stephen F. Austin State University, Nacogdoches, TX 75962

Stephen F. Austin State University is known as the "University Among the Pines." The campus is located along the banks of LnNana creek in the center of Nacogdocha, the oldest town in Texas. Rich with history, the community and the university are now recognizing that cultural. historical and landscape treasure deserve greater protection and conservation. This project involves: 1) collecting a data set of each tree on campus including quadrant identifier, plant ID \#, species, dbh, tree health, location, crow diameter, tree height and tree value, 2) placing all trees on a campus map in $\operatorname{ArcCAD}^{\circ}$, a Geographic Information System (GIS) developed for the PC, 3) linking map entities (trees, polygons, themes) with specific rows in a database, and 4) developing a query strategy to ask questions of the landscape. Database queries are powerful analytical tools which can generate resultant maps that answer specific landscape questions. These maps can then be queried again for further analysis. Examples of typical queries might include: 1) illustrate only those pines with a dbh greater than $24 ", 2$ ) identify all oak trees within thirty feet of a building, or 3) illustrate all trees over sixty feet with poor tree health. $\operatorname{ArcCAD}^{\circledR}$ links the easy drafting capabilities of AutoCAD with much of the functionality of a true GIS workstation. Map files can be linked to a database(s), text, and visual images (TIF files). We have scanned and are currently archiving old photographs of the campus for future linkages. By understanding the history of the university landscape and documenting the current status of campus vegetation, decision-makers can have at strategies that lessen the impact of development.

USE OF COWPEA AS A GREEN MANURE TO REDUCE EXTERNAL NITROGEN INPUTS IN A FALL BROCCOLI CROP Judith L. Rose* and Brian A. Kahn, Department of Horticulture and Landscape Architecture, Oklahoma State University,

Stillwater, OK 74078-0511

Cowpea [Vigna unguiculata (L.) Walp.] was grown as a green manure preceding a fall crop of broccoli [Brassica oleracea L. (Italica Group)] in 1992 and 1993. Urea was used to supply 0,84 , or $168 \mathrm{~kg} \cdot \mathrm{ha}^{-1}$ of supplemental nitrogen $(\mathrm{N})$ to broccoli which followed cowpeas. Control broccoli plots were grown on fallowed ground and were supplied with 168 $\mathrm{kg} \cdot \mathrm{ha} \mathrm{a}^{-1}$ of $\mathrm{N}$ from urea. Cowpea incorporation added over $100 \mathrm{~kg} \cdot \mathrm{ha} \mathrm{a}^{-1}$ of $\mathrm{N}$ to the soil in both years. In 1992, treatments had no significant effect on yield of marketable broccoli heads, but average head weight was reduced in the absence of external N. In 1993, broccoli yield was reduced following cowpeas except when $168 \mathrm{~kg} \cdot \mathrm{ha}^{-1}$ of external $\mathrm{N}$ also was supplied. Broccoli which followed cowpeas was delayed in maturity by 5 to 9 days in 1993 We conclude that a preceding cowpea crop alone will not supply enough $\mathrm{N}$ to sustain acceptable broccoli production. Further studies will determine how much external $\mathrm{N}$ must be supplied when broccoli follows cowpeas, and the best timing for supplying external $\mathrm{N}$. We also will Investigate possible detrimental effects of the preceding cowpea crop on the broccoli.

\section{PROTOPLAST ISOLATION AND CULTURE OF KENAF (HIBISCUS} CANNABINUS L.)

Donglong Liu* and Nancy A. Reichert, Department of Plant and Soil Sciences, Mississippi State University, Box 9555, Mississippi State, MS 39762

Protoplast isolation and culture protocols were developed for leaf tissue from 6 kenaf cultivars [Everglades 41 (E41), E71, Guatemala 4 (G4), G45, G51, and Tainung 1]. For protoplast isolation, the best combination of hydrolytic enzymes was cellulysin $(1 \% \mathrm{w} / \mathrm{v}$; Calbiochem) plus macerase $(0.5 \% \mathrm{w} / \mathrm{v}$; Calbiochem $)$, with a 24 hour digestion at $30^{\circ} \mathrm{C}$ in the dark. Yields reached $7.2(10)^{6}$ protoplasts/g leaf tissue. Protoplast viabilities ranged from $65 \%$ to 96\%. Minor cultivar differences were observed related to protoplast yield, but all viability estimates were in an acceptable range. Greatest cell division frequencies and plating efficiencies were obtained when protoplasts were initially cultured in liquid medium at a density of $1.0(10)^{5}$ protoplasts $/ \mathrm{ml}$. Electrofusion protocols were developed for kenaf protoplasts testing the range from 1200 to $3000 \mathrm{~V} / \mathrm{cm}$. A fusion voltage of $2000 \mathrm{~V} / \mathrm{cm}$ yielded the highest fusion frequency and retained viability above $80 \%$.

URBAN TREE. INITIAL PLANT SIZE GROWTH AS INFLUENCED BY SITE AND INITIAL PLANT GIZE

D.M. Lauderdale*, C.H. Gilliam, D.J. Eakes, and G.J. Keever, Department of Horticulture, Auburn University, Auburn, AL 36849 Two tree species, Acer rubrum 'October Glory' (October Glory red maple) and Quercus phellos (willow oak) were planted in Columbus, GA and Mobile, AL. Variables evaluated were location (park vs residential) and tree size (1.5 vs 3.0 inch caliper). Greater shoot elongation occurred with 1.5 inch red maples and willow oaks than with 3.0 inch caliper trees. First year growth differences were not related to photosynthesis, night respiration, leaf water potential, or foliar nitrogen levels. Little height or caliper change occurred with either species. Red maple shoot elongation was greater in Mobile than in to Columbus. Growth was not affected by location within either city.

HERBICIDE-BLENDED AND COATED FERTILIZER EFFECTIVELY CONTROLS PROSTRATE SPURGE IN CONTAINERS

C.K. Crossan*. C.H. Gilliam, G.J. Keever, and D.J. University, Auburn, AL 36849

Herbicide-blended and coated fertilizers were evaluated for prostrate spurge controlin containers. Ronstar $2 \mathrm{G}$ or Pennant $5 \mathrm{G}$ was blended with Nursery Special 12-6-6 fertilizer and Ronstar 
$50 \mathrm{WP}$ or Pennant $7.8 \mathrm{E}$ was sprayed on the fertilizer (coated). Ronstar 2G-blended fertilizer and Ronstar. 50WP-coated fertilizer provided weed control at the 4,8 , and $161 \mathrm{~b}$ ai/A rates similiar to broadcast (2G) or sprayed (50 WP) herbicide applied at the 1 abel rate (4 1b ai/A). Ronstar provided better prostrate spurge weed control than Pennant. Formulation had no affect on weed control when comparing blended or coated fertilizer. Herbicide-blended and coated fertilizers provided effective prostrate spurge contol in containers.

GERANIUM PRODUCTION AS INFLUENCED BY THREE METHODS OF IRRIGATION USING A CONTROLLED RELEASE FERTILIZER

PatriciaR. Knight*. D. Joseph Eakes, Charles H. Gilliam. and Harry G. Ponder, Department of Horticulture, Auburn University, Auburn University, AL 36849-5408 Seed geraniums (Pelargonium x hortorum Bailey 'Scarlet Elite') were grown in $10-\mathrm{cm}$ pots in a 1 pine bark: 3 peat moss : 1 perlite medium from 18 March until 5 May 1993. Plants received Osmocote $14 \mathrm{~N}-6.1 \mathrm{P}-12.5 \mathrm{~K}$ and either conventional overhead (CO), drip (DI), or subirrigation (SI). Subirrigation produced greater shoot and root dry weights than $\mathrm{CO}$ or DI. Plants grown using DI produced fewer branches than plants grown using $\mathrm{CO}$ or SI. Plants receiving SI reached anthesis before plants receiving CO or DI. Method of irrigation had no influence on total root, soil, or leachate $\mathrm{N}$, but SI did increase total shoot $\mathrm{N}$.

STYRENE-LINED AND COPPER-COATED POTS AFFECT MAPLE GROWTH

$\frac{\text { T.J.Brass*, G.J. Keever, C.H. Gilliam, and D.J. }}{\text { Eakes Department of Horticulture, Auburn }}$ University, AL 36849

Red maple cultivars 'October Glory' and 'Northwood' were grown in 7 gallon containers to determine the influence of styrene lining and copper coating of containers on container medium temperature and growth of red maple cultivars. Copper coating effectively reduced circling of roots at the container wall-medium interface. Root control with copper was less effective on 'October Glory' (a more vigorous cultivar) than on 'Northwood'. Height, caliper, and root dry weight also were less for 'Northwood'. In the absence of copper, surface-root coverage was greater in foamlined containers than in containers without foam where temperatures averaged $10^{\circ} \mathrm{C}$ higher.

VEGETATIVE GROWTH AND NITROGEN FIXATION OF PIGEONPEA AND COWPEA AT THREE TEMPERATURES Raymond Baptiste*, Lurline Marsh Dyremple Marsh, Department of Agriculture, Lincoln University, Jefferson City, MO 65102, and David Trinklein, Department of Horticulture, University of Missouri, Columbia, MO 65211.

Low temperatures adversely affect legume- Rhizobium symbiosis in the temperate regions. Plant growth and $\mathrm{N}$-fixation of two pigeonpea and two cowpea genotypes were examined at three temperature regimes $(20 / 10 \mathrm{C}, 30120 \mathrm{C}$ and $38 / 25 \mathrm{C}$ day/night). Sterilized seeds were inoculated with broth culture containing approximately $1 \times 10^{9}$ cells $\mathrm{ml}^{-1}$ of Bradyrhizobium USDA 3278,3458 and 3472 . Nitrogen fixation by pigeonpea was inhibited at 20/10 C. Cowpea IT82E-16 inoculated with USDA 3458 at $20 / 10 \mathrm{C}$ produced the greatest amount of nodules. Inoculation had no effect on Nitrogenase activity in pigeonpea. Pinkeye Purple Hull inoculated with USDA 3472 at $20110 \mathrm{C}$ had the highest Nitrogenase activity. These results indicate a wide degree of variability among genotypes and Bradyrhizobium in their response to temperature.
INHIBITION OF TAP ROOT ELONGATION IN CONTAINERS BY SIX DIFFERENT MATERIALS COATED WITH SPIN OUTTM

Randon J. Krieg* and Willard T. Witte, Department of Ornamental Horticulture and Landscape Design, University of Tennessee, Knoxville, TN 37901-1071

Tap roots of two coarse rooted species, Nyssa sylvatica and Quercus acutissima. were subjected to six treatment materials which were cut to fit or placed on the bottom of a 7.61 container. Each treatment material (paint only, Styrofoam plug tray, 3M floor buffer mat, peat fiber sheet, stone and weed barrier fabric) was either painted with Spin Out ${ }^{\mathrm{TM}}$ of impregnated with Spin Out ${ }^{\mathrm{TM}}$ WP. Treatments that allowed the tap root to penetrate the material, i.e. weed barrier fabric, stone and $3 \mathrm{M}$ floor buffing mat, were more effective in controlling tap root elongation. The weed barrier fabric significantly reduced tap root length of Quercus acutissima and Nyssa sylvatica by $80 \%$ and $67 \%$ respectively compared to controls and by $65 \%$ and $53 \%$ respectively compared to the paint only treatment. In some cases the $3 \mathrm{M}$ and stone treatments were more effective than the weed barrier fabric but were impractical because of weight or expense.

COMPARISON OF THE PHYSICAL AND CHEMICAL PROPERTIES BETWEEN CONTAINER-GROWN WOODY ORNAMENTALS.

April D. Edwards* and Steven E. Newman, Department of Plant and Soil Sciences, Box 9555, Mississippi Agricultural and Forestry Experiment Station, Mississippi State, MS 39762.

Adolph J. Laiche, South Mississippi Branch Experiment Station, Box 193, Poplarville, MS 39470.

Kenaf (Hibiscus cannabinus) is an alternative fiber crop being grown in Mississippi that maybe used as a tree-less fiber substitute for making paper. A by-product in this process is the pithy light-weight fiber core. The objective of this study was to examine the chemical and physical properties of kenaf fiber core as a medium component in growing woody ornamentals and compare to pine bark. Comparisons of media in which Ilex crenata 'Cheroke' and Rhodoendron eirocarpum 'Wakabuisi' were grown were made. The physical and chemical properties including bulk density, total pore space, water retention, $\mathrm{pH}$ and soluble salt concentrations were determined. Aged kenaf had lower $\mathrm{pH}$ values than fresh and both aged and fresh kenaf had higher $\mathrm{pH}$ values than pine bark. The total pore space of kenaf was lower than the pore space of pine bark. At the termination of the study, the kenaf media had considerable shrinkage, which was considered unsuitable for a long-term crop.

\section{STRATEGIES FOR REDUCING PESTICIDE AND FERTILIZER INPUTS} IN PECAN ORCHARDS

N.R. Rice*, M.W. Smith, R.D. Eikenbary D.C. Arnold, Oklahoma State University, Stillwater, OK 74078, W.L. Tedders, B.W. Wood, USDA/ARS Byron GA 31008, G.G. Taylor, B.S. Landgraf, and G.E. Barlow, Noble Foundation, Ardmore, OK 73402

Annual legume ground covers were evaluated in pecan (Carya illinoinensis) orchards to supply nitrogen and increase beneficial arthropods. Treatments were established at two sites, each with 5 ha of a 'Dixie' crimson clover (Trifolium incarnatum) /hairy, vetch (Vicia villosa) mixture and 5 ha of grass sod. Data indicated that the legume mixture supplied over 100 $\mathrm{kg} \cdot \mathrm{ha}{ }^{-1} \mathrm{~N}$ to the pecan trees. Beneficial arthropods were greater in orchards with legume ground covers than in orchards with a grass groundcover. Lady beetles and green lacewings were the most important spring predators, and green lacewings were the most important fall predator. The Species distribution on the ground covers differed from that in the canopy. Coleomegilla maculata lengi, Hippodamia convergens and Coccinella septempunctata were the most abundant lady beetle species in the legume ground covers, and Olla v-nigrum, Cycloneda munda, and Hippodamia convergens were the most abundant species in the pecan canopies. Beneficial arthropods appeared to suppress injurious pecan aphids. 


\section{Vegetable Crops}

TFE EFFECT OF FLOWER REMOVAL ON THE YIELD OF EARLY AND LATE MATURING SWEETPOTATO (IPOMOEA BATATAS L) CULTNARS

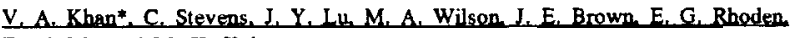
T. Mafole and M. K, Kabwe.

Department of Plant \& Soil Science. Tuskegee University, Tuskegee Institute AL. 36088

TU-155 and Georgia-Jet early, TU-1892 and Carver late maturing sweetpotato cultivars. were evaluated in the field to determine the effect of flower removal (FR) would have on marketable storage, root numbers and yield. Other parameters measured were leaf area and numbers, plant fresh and dry weight. Plants were sampled at 57 and 71 days after transplanting (DAT). All flowers were hand removed and the 1st harvest began 45 days DAT for the early and at 60 DAT for the late maturing cultivars. All flower harvests concluded 22 days after 1st harvest began and roots were harvested 120 DAT. There was significant differences among cultivars for total flower production with $\mathrm{N}-1892$ and Georgia-Jet having the highest flower production. FR treatments for $\mathrm{N}-155$ and Georgia-Jet showed significant increases for plant dry weight, leaf area and numbers 71 DAT while Carver and TU-1892 showed no significant differences for the same sample period. Marketable root numbers were not significantly affected by FR but marketable yields for all cultivars were. Overall, the cultivars showed variation both within and among maturity groups in their response to FR treatments, for example N-155 had a 39\% compared to 3\% increase for Georgia-let while Carver had a $15 \%$ increase in marketable yield compared to $5 \%$ for TU-1891.

\section{ALTERING NUTRIENT SOLUTION N:K RATIO TO}

INCREASE YIELDS OF SWEETPOTATO GROWN IN NFT.

D.G. Mortley, P A. Loretan, A.A Trotman, P. P David, and L.C

Garner, G. W. Carver Ag. Expt. Station, Tuskegee University,

Tuskege e A L 36088

The effects of altering, nutrient solution $\mathrm{N}: \mathrm{K}$ ratio on growth of 'TI155 ' sweetpotato [Ipomoea batatas (L.) Lam] was evaluated in a greenhouse, as part of NASA's Closed Ecological Life Support Systems (CELSS) program for long duration space missions. Vine cuttings of 'TI-155, were grown using nutrient film technique (NFT) in a modified half Hoagland's solution in channels $(0.15 \times 0.15 \times 1.2 \mathrm{~m})$. Plants were grown for 42 days in a culture solution in which $\mathrm{N}$ was doubled $(6 \mathrm{mM})$ in order to accelerate foliage growth after which treatment $\mathrm{N}: \mathrm{K}$ ratios of $1: 2.4$, (control) $1: 4.8$, and $1: 7.2$ were initiated. A randomized complete block design with 4 replications was used. The number of storage roots/plant increased linearly as $\mathrm{K}$ was increased in the solution. Storage root fresh and dry weights, growth rate $\left(\mathrm{g} \mathrm{m}^{-2} \mathrm{~d}^{-}\right.$ ${ }^{1}$ ), fibrous root dry weight, foliage fresh and dry weights, and edible biomass index (root mass/total plant mass), though not significant all increased as $\mathrm{K}$ was increased in the nutrient solution. Nutrient solution analyses showed that $\mathrm{K}$ uptake was greatest in plants at the highest $\mathrm{K}$ level, while nitrate uptake was steady over the duration of crop growth regardless of treatments.

\section{GROWTH ANALYSIS OF A SWEETPOTATO CULTIVAR GROWN} IN AN NFT SYSTEM

Pauline P. David*. Audrey A. Trotman and Desmond G. Mortley

G. W. C. Experiment Station, Tuskegee University, Tuskegee, AL 36088. One of the major objective of growth analysis data is to provide a basic understanding of some of the mechanisms that affect plant growth. This study was initiated to evaluate the effects on several growth parameters when plants are grown in an NFT system. Vine cuttings (15 $\mathrm{cm}$ length) of the sweetpotato cultivar "Georgia Jet" was grown in a closed NFT system for a period of 120 days. Nutrient was supplied in a modified half-strength Hoagland's solution with a N:K ratio of 1:2.4. Destructive harvesting of plants occurred at 14 day intervals at which time plants were separated into their various component parts and analyzed for dry weight accumulation, leaf area index, crop growth rate, relative growth rate and net assimilation rate. Results showed dry weight distribution within the plant had a linear response for all component part evaluated. Greatest contributors to total plant dry weight was stem followed by leaves, fibrous roots, buds and flowers. However, once storage root production occurred it contributed the largest percentage to total plant dry weight. LAI was optimum at 80 days after planting (DAP) while CGR and RGR fluctuated throughout the growing season. Initially NAR was higher in foliage than storage roots but declined once storage root enlargement began, suggesting a translocation of assimilates to storage root.
CONTINUOUS USE OF PLANT NUTRIENT SOLUTION FOR HYDROPONIC CULTURE OF SWEETPOTATO:

IMPLICATIONS AND EFFECTS

A.A. Trotman,* P.P. David and D.G. Mortley, G.W. Carver Agricultural Experiment Station, Tuskegee University, Tuskegee, AL 36088.

In a greenhouse study, continuous use of the same plant nutrient solution for hydroponic culture of sweetpotato was investigated to determine the effect on storage root yield, plant growth and nutrient solution composition. Plants were grown for 120 days under continuous flow from a 30.4-liter reservoir. Plant growth was compared when nutrient solution was changed at 14-day intervals and when nutrient solution was not changed but nutrients replenished through addition of a Modified half-Hoagland's ( $\mathrm{N}: \mathrm{K}=1: 2.4)$ plant nutrient solution when volume in reservoir was -10 liters. Storage root yield was significantly decreased (181 vs $310.3 \mathrm{~g} / \mathrm{plant})$ and foliar biomass was significantly increased ( 372.4 vs $2 \% \mathrm{~g} / \mathrm{plant}$ ) when nutrient solution was not changed Nitrate and phosphate concentrations decreased in the plant nutrient over the duration of the experiment while sulfate and chloride concentrations increased. Salinity and electrical conductivity were monitored at 2-day intervals and increased with duration of the crop. Increased foliage production may have been the result of nitrogen replenishment going largely for foliage rather than storage root production. It may be that continuous use of the same plant nutrient solution as practiced in this study, resulted in lowered phosphate and nitrate concentrations that limited uptake of these ions by sweetpotato plants, thus reducing yield

RESPONSE OF THREE SWEET-POTATO CULTIVARS

GROWN IN NFT TO DIFFERENT IRRADIANCE LEVELS

S. Burrell*, D. Mortley, P. Loretan, A.A Trotman, and P. P David, G. W. Carver Ag. Expt. Station, Tuskegee University, Tuskegee AL 36088

The effects of light intensity on three sweetpotato cultivars [Ipomoea batatas (L.) Lam] were evaluated in growth chambers, as part of NASA's Closed Ecological Life Support Systems (CELSS) program for long duration space missions. Vine cuttings of 'TI-155', 'GA Jet', and TUJ1 were grown using nutrient film technique (NFT) in a modified half Hoagland's solution with a $1: 2.4 \mathrm{~N}: \mathrm{K}$ ratio in channels $(0.15 \times 0.15 \times 1.2 \mathrm{~m})$. Plants were exposed to irradiance levels of 360 or 720 umols $\mathrm{m}^{-2} \mathrm{~s}^{-1}$ with an 18/6 photoperiod in a randomized complete block design with two replications. Temperature was set at 28:22 lightdark and RH was $70 \%$. Differences in plant response to were more related to cultivars than the effect of light intensity. Storage root number (8) fresh, (786 g/plant) and dry weights (139 g/plant) were highest for 'TI-155' while foliage fresh and dry weights were highest for 'TUJ1' when averaged across light levels. TI-155' (921 g/plant) and 'GA Jet' (538 g/plant) produced greater yields at higher irradiance. 'TUJ1' produced a higher yield (438 g/plant at the lower intensity compared to 219 (g/plant) at the higher intensity, suggesting this cultivar could produce storage roots in similar conditions in a CELSS.

SEEDING AND COVERING DATES FOR PRODUCING 'TEXAS GRANO 1015Y' ONION TRANSPLANTS UNDER ROW COVERS Bender. David A.*, Texas Agricultural Experiment Station, Lubbock, TX 79401-9757

Field production of adapted transplants could allow West Texas growers to meet the strong demand for 'Texas Grano 1015Y' onions in June. A trial was conducted to determine optimal timing for seeding and covering field beds with row covers to produce transplants for planting in early March. Onions were seeded in drip-irrigated field beds at 10-day intervals from mid-October to mid-November and covered with 4-mil polyethylene tunnels at 10-day intervals from midNovember to mid-December. Plants were evaluated on 11 March and transplanted into field plots with greenhouse-grown plants. Seeding in October or covering in mid-November produced acceptable 4-leaf transplants by early March. Plant height, dry weight, number of leaves and survival decreased as seeding or covering was delayed. In field trials, row cover plants produced equal yields and only slightly smaller bulbs than greenhouse plants. Despite the large size of some of the field-grown transplants, no bolting was observed.

SIMULTANEOUS SCREENING FOR VIRUS AND NEMATODE RESISTANCE IN SOUTHERNPEA, VIGNA UNGUICULATA

A. G. Hunter* and O. L. Chambliss, Department of Horticulture, 101 Funchess Hall, Auburn University AL 36849 Screening for resistance to blackeye cowpea mosaic virus (B1CMV) and rootknot nematode on the same plant is possible if the two pathogens do not interact significantly. To determine if such interactions were present four cultivars were planted in 72-cell styrofoam flats, with a combination of B1CMV and nematode inoculations (--, -+, +and ++). 'Freezegreen' is known to be susceptible to both 
pathogens, 'Mississippi Silver' is resistant to both, 'California Blackeye \#5' is susceptible to B1CMV, and 'Worthmore' is resistant to BlCMV. Nematode treated seeds were inoculated at planting with 2,000 eggs of (Meloidogyne incognita Race 3); BlCMV was inoculated on primary leaves a week later. Plants were visually rated for symptoms: either negative or positive for BlCMV and 1-5, no galls and heavily galled respectively, for rootknot. Analyses of variance using percentage of plants negative for virus symptoms or average nematode score as the dependent variable, resulted in non-significant virus $x$ nematode interactions. Results by cultivar indicated simultaneous screening did not change their resistance/susceptible classifications.

\section{TOMATO TRANSPLANT AGE AND METHOD OF PLANT HARDENING AFFECT YIELD}

Warren Roberts* and Jim Duthie, Wes Watkins Agricultural Research \& Extension Center, Oklahoma State University, Box 128, Lane, Oklahoma, 74555

Wet soils can prevent growers from transplanting tomatoes at the ideal size and age. Experiments were conducted to determine the length of time that transplants can be held before yield is reduced Also, different techniques for holding and hardening plants were compared. Seven ages of 'Sunny' tomato plants $(4,5,6,7,8,9,10$ weeks old at transplanting) were either grown normally, grown with limited water, or grown with limited fertilizer. Plants were grown in trays containing 128 cells, with each cell approximately 3.2 by 3.2 by $11 \mathrm{~cm}$. Water was applied for 3 minutes either once a day or twice a day. Fertilizer (20-20-20) was applied either once a week or once during the entire seedling production period. Transplants were later planted in the field. The experiment was conducted in 1990, 1991, and 1993. The yield response to transplant age was quadratic, with maximum yield occurring with 6,7 , and 8 week old transplants. In general, the greatest yield occurred when water was withheld, and the lowest yield occurred when fertilizer was withheld from the transplants

NEITHER GREEN NOR WHITE ASPARAGUS SPEARS ARE AFFECTED BY SUPPLEMENTAL NITROGEN

D. J. Makus, USDA, ARS, CPSR, Weslaco, TX 78596

'Jersey Giant' asparagus (Asparagus officinalis L.), grown in an Enders silt loam mineral soil near Booneville, Ark., was given an application of $80 \mathrm{~kg} / \mathrm{ha}$ of Supplemental nitrogen $\left(\mathrm{N}\right.$, as $\left.\mathrm{NH}_{4} \mathrm{~N} \mathrm{O}_{3}\right)$ either prior to or after the Cutting season in 1993. Neither N treatment affected spear objective Color, Pigments, soluble solids concentration (SSC), or yield. Supplemental N decreased spear $\mathrm{Ca}$ and $\mathrm{K}$ levels. Green asparagus had higher levels of total-N, K, S, P, Ca, Mg, Fe, Zn, Al, Mn, and $\mathrm{Cu}$, but lower levels of $\mathrm{NO}_{3}$ than did white asparagus. As the Cutting season progressed, spear $\mathrm{SSC}, \mathrm{S}, \mathrm{Ca}, \mathrm{NO}_{3}\left(\mathrm{NO}_{3}\right.$ in White spears only), $\mathrm{Zn}, \mathrm{Mn}$, and $\mathrm{Cu}$ ( $\mathrm{Cu}$ in white spears Only) levels decreased, While spear $\mathrm{K}$ and $\mathrm{Al}$ (Al in white spears only) increased on a dry weight basis. Fall residual soil $\mathrm{NO}_{3}$ levels were not affected by $\mathrm{N}$ application, but organic matter was lower in soil which received early supplemental $\mathrm{N}$.

PLANT SPACING, COLD TREATMENT, AND FLOWER VIBRATION INFLUENCE ON GREENHOUSE TOMATO PRODUCTION

Benjamin G. Mullinix*. Sharad C. Phatak, \& Janet Cooper, Depts. of Statistical \& Computer Services, and Horticulture, University of Georgia Coastal Plain Experiment Station, Tifton, GA 31793-0748

Six tomato cultivars [Hotset, Petra, Stella, Big-O, Tropic, \& Monte Carlo (fresh market)] were grown in a greenhouse in 1979 from July through November in 3 experiments. Exp. 1: The first two cultivars were used in a $15 \mathrm{~cm}, 30 \mathrm{~cm}$, or $45 \mathrm{~cm}$ in-row spacing with rows spaced $60 \mathrm{~cm}$ apart. Cumulative fruit number and weight per unit area declined with increasing in-row spacing. Exp. 2: The first four cultivars were subjected to either cold or no cold treatment during germination before transplanting. No differences were found between the two treatments for mean fruit weight or total fruit number. Exp. 3: The last two cultivars were subjected to both the cold treatment and flower vibration. Cumulative fruit weight was greater for vibrated flowers. Greater mean fruit weight occurred earlier with cold treatment and declined significantly later in season, and was more pronounced in Tropic than Monte Carlo.
DIFFERENTIAL FRUIT DETACHMENT FORCE OF MATURE CAYENNE PEPPER SELECTIONS

Kay P. Gersch*, Carl E. Motsenbocker, and Gregory A. Lang, Dept. of Horticulture, Louisiana State University, Baton Rouge, LA 70803

Cayenne pepper fruit adhere tightly to the calyx/receptacle, increasing the cost of hand harvest and restricting mechanical harvest. Eight (8) cayenne pepper genotypes were selected from field observations to characterize fruit detachment forces(FDFs) and examine potential relationships between FDF and other fruit parameters. A preliminary greenhouse experiment revealed two genotypes with consistently lower FDFs and two with consistently higher FDFs over several progressive harvest. A field experiment confirmed these characteristics. No correlation between any fruit parameter and FDF was found to be consistent over the genotypes studied.

VEGETABLE YIELD AND SOIL NUTRIENT CONTENT ARE AFFECTED BY POULTRY LITTER AND ROTATION WITH WHEAT B.D. McGraw* and B. Bostian, Department of Horticulture, Oklahoma State University, Stillwater, OK 74078

In March 1992 treatments were established in a split plot design to compare vegetable yield and nutrient buildup effects of $94 \mathrm{~kg}$ of 34-0-0, 1345 and $2692 \mathrm{~kg} / \mathrm{ha}$ spent poultry litter under fallow or wheat rotation cover. The $2692 \mathrm{~kg}$ litter treatment caused a nonsignificant decrease in 'Crimson Sweet' watermelon yield. Wheat was planted on half the plot area in September 1992 and harvested in March 1993. Fertilizer and litter treatments were reapplied in April and 'Merit' sweet corn was planted. Corn plant growth was more vigorous and yield was significantly higher in fallow plots irrespective of litter treatment. Sweet corn yield was highest in plots treated with $2692 \mathrm{~kg}$ liter/ha. $\mathrm{NO}_{3}, \mathrm{~K}, \mathrm{SO}_{4}$, and $\mathrm{Mg}$ content of the top $30 \mathrm{~cm}$ of soil was decreased by wheat. Soil nitrate level remained below the pretreatment level after the first year except for the $2692 \mathrm{~kg}$ litter/fallow treatment. Soil P at the 0-30 $\mathrm{cm}$ depth remained the same as or higher than the initial level in all treatments. Soil K content exceeded initial test levels in all fallow treatments and one wheat treatment.

COMPARATIVE EFFECTS OF SOIL SOLARIZATION AND OTHER AGRIPLASTIC MULCH SYSTEMS ON INCREASED GROWTH RESPONSE AND REDUCTION OF EARLY BLIGHT DISEASE OF FLORADADE TOMATO

C. Stevens, V. A. Khan, M.A. Wilson*, D. J. Collins. J. E. Brown and J. Y. Lu.

Department of Plant \& Soil Science, Tuskegee University. Tuskegee Institute AL. 36088

Agriplastic black mulch (BM), row cover (spunbonded) plus black mulch (RBM) and solarized soil treatments plus black mulch (SBM). row cover plus black mulch on solarized soil (RSBM) and row cover plus solar\&d soil (RSBS) increased Floradade tomato yield from 56 to $285 \%$ number of tomatoes and plant height compared to the non-solarized bare soil (BS). When comparing increased growth response (IGR) of the plants grown in the solarized soil with no row cover agriplastic treatments, there was no significant differences among them. When comparing the IGR parameters of tomato plants grown under SBS, BM, and RBS there were no significant differences among them. Spunbonded row cover treatments increased IGR of tomatoes over all treatments without row cover. A significant increase in plant growth promoting rhizobacteria (PGPR) was observed in the rhizosphere soil of Floradade tomatoes grown in solarized soil alone and in those other agriplastic treatments compared to bare soil. There appear to be no differences in PGPR population among SBS and all agriplastic treatments.

STAND DEFICIENCIES AND REPLANTING EFFECTS ON BELL PEPPER YIELDS

Regina P. Bracy*, Louisiana State University Agricultural Center, Louisiana Agricultural Experiment Station, Hammond Research Station, 21549 Old Covington Hwy., Hammond, LA 70403

Bell pepper plant losses at transplanting may reduce yields. Growers often use subjective visual observations to determine reductions in plant stand but do not have a basis for determining if missing plants should be replaced or how soon. This study was initiated to determine effects of stand deficiencies and replanting on yield and fruit size of pepper during the spring 1992 and 1993.

'Jupiter' bell pepper plants were transplanted to the field in late March and spaced $30 \mathrm{~cm}$ apart on $1.2 \mathrm{~m}$ beds mulched with black plastic. Treatments included a control $[0 \%$ stand deficient (SD)] and 10, 20, or 30\% SD plots that were established at transplanting. Each SD treatment was replanted to a $100 \%$ stand two 
or three weeks after initial transplanting or was not replanted.

Yield of extra-large and marketable fruit was not affected by stand deficiencies or replanting in either year. Stand deficiencies up to $30 \%$ did not result in reductions in total/early yield or fruit size.

BULK PLANTING SYSTEM FOR LOW-COST SEEDING OF CABBAGE Wayne C. Porter* and Richard L. Parish, Louisiana State University Agricultural Center, Louisiana Agricultural Experiment Station, Hammond Research Station, Hammond, LA 70403 and Dept. of Biological and Agricultural Engineering, Baton Rouge, LA 70803

The initial investment of a precision seeder is cost prohibitive to many small vegetable growers. This study was initiated to evaluate the use of a relatively inexpensive bulk seeder to plant cabbage (Brassica oleracea L. Capitata). Cabbage was direct-seeded with a precision seeder or a relatively inexpensive bulk seeder. Treatments with the bulk seeder consisted of blending viable hybrid seed with nonviable, nonhybrid seed at several ratios to reduce hybrid seed cost and optimize plant spacing. Seed ratios represented $10,20,30,40,50$, and $100 \%$ viable seed. Pre-thin plant stands of 30 and $40 \%$ hybrid seed treatments were similar to precision-seeded plant stands. Average head size was greatest with 10, 20, and $30 \%$ hybrid seed ratios. Marketable yields were similar for all hybrid seed ratios except the $10 \%$ ratio. Production costs per acre for the precision seeder were between that of the 40 and $50 \%$ ratios. Net income for $40 \%$ hybrid seed was similar to that of the precision seeder.

\section{THE TENNESSEE SNAP BEAN INDUSTRY}

Charles A. Mullins and Richard A. Straw, Department of Plant and Soil Science, University of Tennessee, Crossville, TN 38555

Snap beans comprise the largest acreage of any vegetable crop grown in Tennessee with an annual production of about 6,000 hectares. Approximately two-thirds of the production is for five fresh market packers and the rest is primarily for two large processors located within the state. Most production is machine harvested with over 50 harvesters owned by Tennessee producers. Primary fresh market cultivars grown are 'Strike', 'Hialeah', and 'Greencrop'. Fresh market snap beans are mechanically and hand graded to remove small pods, broken pods, and trash. Hydrocooling has become a standard practice in fresh market packing operations. Packed beans are sold throughout most of the Eastern United States. Primary processing cultivars are 'Roma II', 'Trueblue', 'Hystyle'. 'Peak', 'Benton', and 'Labrador'. Snap beans are grown on the Cumberland Plateau and in West Tennessee for nearby processing plants. At present, only a small portion of snap beans grown for processing are shipped out of state.

VEGETATIVE GROWTH OF VEGETABLE AMARANTH AS AFFECTED BY NITROGEN FERTILIZATION

Wayne F. Whitehead* and Bharat P. Singh. Agricultural Research Station, Fort Valley State College. Fort Valley, GA 31030-3298

Influences of nitrogen (N) rate were evaluated on vegetable amaranth. Amaranthus tricolor, grown at uniform populations over two year. The main objective was to determine an optimum level of $\mathrm{N}$ fertilization for successful production in middle Georgia. In 1992 and 1993 accession 'RRC 241' was planted in randomized complete block design on June 19 and 23, respectively. Four $\mathrm{N}$ rates, equally split were evaluated: $0,45,90$, and 135 $\mathrm{kg} \mathrm{ha}{ }^{-1}$. First of the applications were 18 and 13 days post planting for 1992 and 1993, and again when plants were 5 weeks old. Plants were harvested 48 days after planting with green yield, leaf fresh weight. and stem fresh weight collected in both years and leaf area for 1993. In years 1992 and 1993 green yields were 5.3 and $6.5,10.7$ and 9.0.13.2 and 12.1, and 13.5 and $14.0 \mathrm{Mg} \mathrm{ha}{ }^{-1}$. respectively for the $0,45,90$, and 135 rates. In both years vegetative components showed significant regression for all treatments. Vegetative response $\left(R^{2}\right)$ for green yield in 1992 and 1993 was quadratic $(85 \%)$ and linear $(73 \%)$, leaf fresh weight in both years was cubic $(63 \%$ and 48\%), while stem fresh weight response was linear (29\%) and cubic (72\%). During 1993 leaf area was linear (58\%). Non-significance predominantly occurred between the two higher rates for each year and when combined. indicating that $90 \mathrm{~kg} \mathrm{~N}$ ha should provide optimal production of amaranth for the middle Georgia region.

PINE BARK, RICE HULLS, AND OTHER INEXPENSIVE MEDIA FOR GREENHOUSE TOMATO PRODUCTION IN THE SOUTH

Richard G. Snyder*, Mississippi State University, Truck Crops Research \& Extension Center, P.O. Box 231, Crystal Springs, MS 39059.

Successful greenhouse tomato businesses are able to keep production and quality high while maintaining reasonable cost controls. One way of controlling costs is to use growing media that are locally available in good supply, and therefore of low cost. In Mississippi. as in other states in the southeast, pine bark is an available byproduct resource from the forestry industry; fines $(<=95 \mathrm{~mm}$ diameter) can be used as a growing medium following composting. Rice hulls are a readily available waste product from rice mills, especially in the Mississippi Delta region; these are suitable after being crushed and composted.

In comparison to plants grown in rock wool, yield from plants in pine bark fines, rice hulls, or sand were higher, while quality was not significantly different in the 1-crop/year system. In a spring crop, yield and quality were higher from plants in pine bark, rice hulls, and rock wool than from those grown in sand. On a per plant basis, cost for the rock wool system, perlite system (pre-bagged), perlite (bulk), peat moss, sand, composted rice hulls, and pine bark lines are $\$ 1.50, \$ 1.00, \$ 0.35, \$ 0.60, \$ 0.24, \$ 0.22$ and $\$ 0.17$, respectively. Pine bark and rice hulls are good choices for growing media for greenhouse tomatoes in areas where they are available.

RESPONSE OF OKRA TRANSPLANTS GROWS ON SOIL SOLARIZING PLOTS DURING THE ACTIVE PERIOD OF SOIL SOLARIZATION

V.A. Khan*, C. Stevens, J. Y. Lu', D. I. Collins, M. A. Wilson, J. E. Brown M.K. Kabwe, and O. Adeyeye

George Washington Carver Agricultural Experiment Station, Tuskegee University, Tuskegee Institute AL 36088

A study was conducted in 1991 to determine the effect high soil temperature would have on 'Clemson Spineless' okra plants transplanted into field plots during 60 days of active soil solarization (solar heating of the soil using clear plastic during the summer period). Solarized plots were planted to a winter cover crop which served as an organic amendment, which was rototilled into the top 15 $\mathrm{cm}$ of the soil before solarizing. Okra transplants were planted on the outer edges of the plots one month after the solarization process commenced and drip irrigated. Three weeks (wk) after transplanting, a complete fertilizer at the rate of 200 parts per million was applied to the plots giving the following the rate of 200 parts per million was applied to the plots giving the following treatment combinations: solarized non-fertilized control (SNF), non-solarized nonfertilized control (NSNF), solar fertilized (SF). and non-solarized fertilized (NSF). Results showed that the increased soil temperature did not have any deleterious effect on the okra plants grown in SNF or SF plots. However, plants grown in SF plots suffered severe fertilizer bums which affected plant density and yield. This indicated a rapid breakdown of soil organic matter provided sufficien nutrients to sustain a late-season crop of okra. Plant height, marketable yield vegetative branching and income generated were greater in SNF compared to SF, NSF and NSNF plots, respectively.

PERFORMANCE OF CALABAZA (CUCURBITA MOSCHATA) HYBRIDS Donald N. Maynard*, Gulf Coast Research and Education Center, University of Florida, Bradenton, FL 34203; Gary W. Elmstrom, Central Florida Research and Education Center, Leesburg, FL 34748; and Linda Wessel-Beaver, Department of Agronomy and Soils, University of Puerto Rico, Mayaguez, PR 00681

Hybrids from crosses between bush/short-vined breeding lines and traditional, vining cultigens were evaluated in the fall 1993 season. Yields of individual hybrids were 0.51 to 1.73 times those of their vining parents and 0.83 to 4.41 times those of the bush/short-vined parents. The average yield response of 58 hybrids was 1.05 times that of vining parents and 2.15 that of bush/short-vined parents. Average fruit weight, flesh thickness, and flesh color of the hybrids tended to be intermediate between that of the bush/short-vined and vining parents. Plant habit of all hybrids was similar to that of the bush/short-vined parent early in the growth cycle, but some became viney later in the growth cycle. Fruit matured earlier on bush/short-vined parent and hybrid plants than on viney parent plants.

\section{INFLUENCE OF VARIETY AND LOCATION ON FLESH COLOR IN} POTATO

Mohamed S. Al-Saikhan*, Luke R. Howard and J. Creighton Miller. Jr., Department of Horticultural Sciences, Texas A\&M University, College Station, TX $77843-2133$

The influence of variety and location on flesh color was examined using Texas and Colorado grown tubers from ten yellow flesh and two white flesh potato varieties. Flesh color was determined using a Hunter Colorimeter, which gives three readings, $L^{*}$ (lightness to darkness), $a^{*}$ (green-red index) and $b^{*}$ (blue-yellow index) Three readings were taken from each tuber at the distal end, center, and stem end. There were significant differences in color among varieties grown in each location for $\mathrm{L}^{*}$, and at both locations, the center was darker. The distal end had the highest chroma and hue angle values at both location. Significant differences were found between the same variety grown in both locations for $\mathrm{L}^{*}$, chroma, and hue. Chroma and hue were greater in Texas grow tubers which indicated more redness. Lower mean hue angle values indicated that Texas tubers were more red, whereas Colorado tubers were yellow. Higher mean chroma values indicated that Texas grown tubers were redder than Colorado grown tubers. L* chroma, and hue angle are the most useful quantitative measurements. 
EXPOSURE TO CHILLING TEMPERATURES REDUCES GROWTH AND YIELD OF 'SUPERSTAR' MUSKMELON.

W.D. Scott*, Purdue University, Southwest Purdue Ag. Center,

R.R. 6 Box 139A, Vincennes, IN 47591

Greenhouse and field studies were conducted using research coolers to expose 4 week old 'Superstar' muskmelons, planted into 1 liter plastic containers, to chilling temperatures. Temperatures of $1,5, \& 9{ }^{\circ} \mathrm{C}$ were arranged in factorial combination with lengths of exposures $6,12, \& 24$ hours and number of exposures $1,3, \& 5$. In the Greenhouse studies single plant experimental units were allowed to grow for 2 weeks following application of the chilling treatments, then growth data was taken. In field studies, exposed muskmelons were planted into 8 plants/plot units when all plants had received chilling treatments. Leaf area and plant dry weight of 'Superstar' melons were significantly reduced by both the interaction of temperature and length of exposure and times exposed and temperature, with dramatic reductions in leaf area occurring at 24 hours of exposure or 5 times exposed at $1{ }^{\circ} \mathrm{C}$. A significant interaction was found between times exposed or length of exposure and temperature on vine length, flower number and type measurements taken 4 weeks after chilled transplants were established in the field. Additionally, fruit number and mean melon weight were reduced by ether exposure to 10C, exposure of 24 hours or 3 times exposed.

THE EFFECT OF BIOZYMETM ON EMERGENCE OF BEAN (Phaseolus vulgaris L.) AND SWEET CORN (Zea mays L.) SEEDLINGS UNDER SUBOPTIMAL FIELD CONDITIONS

Armando Campos Cruz*, Douglas C. Scheuring and J. Creighton Miller Jr., Department of Horticultural Sciences, Texas A\&M University, College Station, TX 77843-2133

The effect of Biozyme ${ }^{\mathrm{TM}}$, a commercial germination stimulant, on emergence of bean and sweet corn seeds, treated with four levels of Carbofuran and Chlorothalonil, and grown under suboptimal field temperatures, was evaluated. Half the seeds from each treatment were treated with Biozyme ${ }^{\mathrm{TM}}$ Two planting dates were selected to provide suboptimal temperatures during emergence. Pesticide overdoses caused significant detrimental effects to all emerging seedlings. These effects were magnified under the low temperatures of the first planting. Biozyme $^{\mathrm{TM}}$ treatment significantly improved emergence rate, percent emergence, final stand and number of ears of sweet corn in the first planting, and the percent emergence final stand, plant dry weight, and number of ears in the second planting. In beans, however, Biozyme ${ }^{\mathrm{TM}}$ treatment significantly reduced emergence rate, percent emergence. and final stand in the first planting, while significantly increasing percent emergence, plant dry weight, and seed dry weight in the second planting. The beneficial effects of Biozyme ${ }^{\mathrm{TM}}$ appeared to be independent of the negative effects of pesticide overdoses.

\section{Fruit Crops}

\section{STATISTICAL ANALYSIS OF LONG-TERM PECAN TREE PRODUC- TION}

Benjamin G. Mullinix* and R. E. Worley, Departments of Statistical \& Computer Services, and Horticulture, University of Georgia Coastal Plain Experiment Station, Tifton GA 31793-0748

Three out of many pecan cultivars (Gloria, Pabst, \& Stuart) were examined over long periods of time. The latter two cultivars have been planted since 1921 when the first pecan orchard was established. One tree of each of these cultivars were removed because of overcrowding. Gloria and Pabst were planted in 1954. Best production practices known were used until 1962. Fertilization and insecticide sprays were adopted. In 1970, spraying for disease was adopted. In 1974, drip irrigation and selective limb pruning were adopted. GrowSeason (GS) [(Year-Planted+1)-mean GS] was used in a linear (L), quadratic (Q), or cubic (C) model where the best model was chosen (significant F-test). Yield was expressed as cumulative yield. Older trees tended to produce more after 1962 (C trend), mid-aged trees more after 1970 (Q/C trend), and younger trees more after 1974 (L/Q trend). Younger trees had the greatest average yearly cumulative yield
LONG TERM SELECTIVE LIMB PRUNING INTENSITY FOR

\section{'STUART' PECAN}

Ray Worley Department of Horticulture, University of Georgia, Coastal Plain Experiment Station, Tifton GA 31793-0748

Trees were pruned by removing 1, 2, or 3 leader limbs per year or not pruned from 1975 through 1993. Cuts were made flush with another limb below $9 \mathrm{~m}$ from the ground. Pruning induced trees to respond like younger trees. Pruning increased leaf $\mathrm{N}, \mathrm{P}, \mathrm{Mg}, \mathrm{Mn}, \mathrm{Fe}$, $\mathrm{Zn}$, vigor, color intensity, terminal growth, nut size, and nuts per terminal. Kernel grade was reduced slightly by pruning. Yield was reduced by two or three pruning cuts per year, but not by one cut. Pruned trees were lower, more spreading, and more efficient to spray. Removal of one leader per year satisfactorily held the tree within the $21.3 \times 21.3 \mathrm{~m}$ spacing without reducing yield. The lower height of pruned trees should decrease loss from high winds. All pruned trees survived a hurricane and a small tornado, while many unpruned trees in the area were blown down.

TWO YEARS OF RESULTS ON THE INFLUENCE OF GROWING SEASON TEMPERATURES ON FATTY ACID PROFILES AND OIL CONTENT OF FOUR PECAN CULTIVARS

L. Sistrunk. D. Chapman J. B. Storey*. Texas A\&M University, Dept. of Horticulture. College Station TX 77843-2133

Pecan nuts from eleven different locations ranging from 1000 heat units at Chetopa, Kansas during the twelve weeks prior to shuck split to 1675 heat units in Zavala County, TX. Monounsaturated and polyunsaturated fatty acids increased and decreased respectively in 'Mohawk' in 1991 and 1992 as the temperature increased during the kernel development period Fatty acids in 'Pawnee' responded the same as in 'Mohawk' in 1992 but were variable in 1991. Limited data showed a reversal of mono and polyunsaturated fatty acids in 'Osage' in response to kernel development temperature. Higher temperatures caused the testas of 'Cheyenne' to be darker in 1991 and 1992. Total oil content of 'Mohawk' increased heat units. However, higher temperatures decreased oil content in 'Pawnee'. Clinical evaluation of pecans is needed to confirm Grundy's safflower work.

\section{INTERSTEM LENGTH AND ETHEPHON DO NOT ENHANCE TA TAO} BLOOM DELAY

Gregory L. Reighard*, Clemson University, Department of Horticulture, Box 340375, Clemson, SC 29634

'Juneprince' peach was budded to Ta Tao 24 peach interstems on virusfree Love11 rootstock in June 1990. Trees were planted December 1990 in a fumigated Lakeland sand near Columbia, SC. The experimental design was a randomized complete block with 9 replicates each having 6 treatments plus a control. Four treatments were 20 and $40 \mathrm{~cm}$ interstem segments of Ta Tao 24 with and without an interstem branch. Two other treatments were $40 \mathrm{~cm}$ Ta Tao 24 interstems with no branches but receiving a single November spray of either $200 \mathrm{ppm}$ ethephon or water. The control was 'Juneprince' on Lovell rootstock. After 3 years, control trees were significantly larger in TCSA $(\mathrm{cm} 2)$ than all treatment trees. Full bloom date was not significantly different among the 6 treatments, hut was significantly later (7 days) than the control trees. In March 1993, cold temperatures killed all open flowers on control trees. Fruit yields in 1993 were significantly higher in interstem trees $(10.2 \mathrm{~kg} /$ tree $)$ compared to the control trees $(6.8 \mathrm{~kg} /$ tree $)$. Fruit maturity date did not differ among treatments, hut was significantly later (10 days) than the control trees. 'Juneprince' on Ta Tao 24 interstems were smaller in TCSA and had delayed bloom and fruit maturity. Ta Tao 24 interstem length presence of branches, and ethephon application did not enhance the differences observed in this study.

Plum Production Under Cold Stress

J.D. Norton, C. E. Boyhan, Hongwen Huang, B. R. Abrahams Dept. of Horticulture and Alabama Agricultural Experiment Station, 101 Funchess Hall, Auburn University, AL 36849-5408

On March 13-15, 1993 Alabama and much of the eastern United States experienced an unusually severe winter storm. This afforded the evaluation of plum cultivar production under cold stress. The highest yielding variety that bloomed before the storm was Bruce $12-4$ with $28 \mathrm{~kg} /$ tree. Bruce $12-4$ is noted for blooming over an extended period of time and producing very heavy yields. The average yield of the top five performers that bloomed after the storm was $51 \mathrm{~kg} /$ tree. The lowest temperature recorded at the test site, Shorter, AL was $-5 \mathrm{C}$. 
RESPONSE OF UV-C LIGHT ON THE CONTROL OF BROWN ROT ON SEVERAL PEACH VARIETIES

C. Stevens, L. P. Pusey, V.A. Khan, J.Y. Lu, C.L. Wilson, M.A Wilson*, M.K. Kabwe, J. Liu, E. Chaultz, and S. Droby. Department of Plant \& Soil Science. Tuskegee University, Tuskegee Institute AL. 36088

Flavorcrest, Camden. C. L. Wilson, Loring, Elberta, Summergold and Harken peach varieties were inoculated and naturally infected with Monilinia fructicolo after ultraviolet light irradiation (W-C 254nm) showed increased resistance to brown rot disease. Although dosages ranged from 0 to 20

$\mathrm{KJ} / \mathrm{m} 2$. $7.5 \mathrm{KJ} / \mathrm{m} 2$ was considered the most effective for the peach varieties tested. Pretreatment of peaches by field spraying or dipping into a benomyl fungicide showed no significant differences between non-treated and UV-C treated peaches. However. a combination of a low dose of benomyl $(.15 \mathrm{~g} / \mathrm{L}) 3$ days following UV-C treatment showed a synergistic effect on brown rot reduction when compared to Peaches treated with UV-C alone and a greater reduction of brow rot than benomyl control.

\section{DELAYING BLOOM OF 'LORING' PEACH BY FALL APPLICATION OF GIBBERELLIC}

ACID, ETHEPHON, AND GIBBERELLIC ACID PLUS ETHEPHON.

A. Caylor*. W. Dozier. D. Himelrick, Department of Horticulture, L. Chapman. Alabama Cooperative Extension Service, and J. Pitts, Chilton Area Horticultural Substation, Alabama Agricultural Experiment Station, Auburn University, AL 36849

Four year old 'Loring' peach trees on 'Lovell' rootstock were treated with single applications of 0,50 , and $100 \mathrm{ppm} \mathrm{GA}^{3}$ alone and in combination with $100 \mathrm{ppm}$ ethephon on 15 November 1988, 1989, and 1990 to determine the effect on bloom delay the following spring. Flower bud number was not affected by any of the treatments the next spring. Ethephon had the greatest effect on bloom delay the following spring. The 50 and $100 \mathrm{ppm} \mathrm{GA}^{3}$ treatments resulted in a slight delay of bloom. The combination of 50 and $100 \mathrm{ppm} \mathrm{GA}^{3}$ and 100 $\mathrm{ppm}$ ethephon resulted in less of a bloom delay than ethephon alone but greater than the $\mathrm{GA}^{3}$ treatments alone. Fruit set was increased by ethephon treatments in 1989 and 1991 but not in 1990. Ethephon treatments delayed fruit maturity whereas $\mathrm{GA}^{3}$ did not. Total fruit yield for 1989, 1991, and the three year average was not effected by treatments. However, in $199050 \mathrm{ppm} \mathrm{GA}^{3}$ resulted in the highest yields. Ethephon treatments reduced the average fruit weight in 1990 and 1991 but not in 1989 or the three year average.

STATISTICAL ANALYSIS OF A MULTI-YEAR, SPLIT PLOT DESIGN FOR TREE-FRUIT DATA

Benjamin G. Mullinix*. Dean R. Evert. \& Kerry Harrison, Depts. of Statistical \& Computer Services, and Horticulture, University of Georgia Coastal Plain Experiment Station, Tifton GA 31793-0748

Two peach cultivars (Flordaking \& Junegold) were planted in wheel-spoke design under a center pivot irrigation system. Main plots were sprays (Blast, Cheek, \& Piggy-back) and cultivars. Sub-plots were training systems (Inside, Outside, \& Standard). Sub-sub-plots were tree areas. Four rows were planted with two Inside rows and two Outside rows. Middle two rows of the standard plots were harvested. Intra-row spacing increased the further they were from the center. All trees harvested in 1990, standard plots were harvested every year, and Inside/Outside were harvested in alternate years. Most sources of variation in the model failed to be homogeneous among the 3 years. Since the number of trees harvested each year varied, all mean comparisons were done using the unequal $\mathrm{N}$ - unequal variance $\mathrm{t}$-test.

SPRING Vs. AUTUMN FERTILIZER APPLICATION EFFECTS ON APPLE TREES IN THE MID-SOUTH

Curt R. Rom*, R.A. Allen, K. Kupperman, and J. Naraguma, Department of Horticulture and Forestry, University of Arkansas, Fayetteville, AR 72701

Three studies were established to compare spring (S) vs. autumn (F) $\mathrm{N}$ fertilizer applications on apple tree performance. The studies used newly planted trees, 4-yr-old trees, and 8-yr-old trees, fertilized with either ammonium nitrate or urea at 2 weeks after harvest $(\mathrm{F})$ or at bud break (S). In the first 3 years growth in a newly planted orchard, time of fertilizer did not significantly affect tree height or TCSA. In the first cropping year, F fertilized trees had the greatest flower cluster number and bloom density but similar \% set and yield compared to $\mathrm{S}$ fertilized trees. $\mathrm{F}$ fertilized trees in mature orchards studies tended to be shorter and have smaller TCSA increment after 3 yrs. Treatments did not affect bloom density, \% set or total yield although spring fertilized trees had a greater \% drop. Although spur leaves of $\mathrm{F}$ fertilized trees had greater $\mathrm{N}$ content at bloom, shoot leaves typically had lower $\mathrm{N}$ and $\mathrm{Mn}$, and higher $\mathrm{P}, \mathrm{K}$, and $\mathrm{Ca}$ at 90 days after bloom compared to $\mathrm{S}$ treatment trees.

COLD DAMAGE OF APPLE BUDS AND SPURS FOLLOWING TREATMENT WITH DORMANT OIL

R.E. Myers*. D.E. Deyton, and C.E. Sams, Department of Plant and Soil Science, The University of Tennessee, Knoxville, TN 37901-1071.

Spurs of 'Starkspur Delicious' trees were dipped in 0, 3, 6, 9 or $12 \%$ petroleum oil (dormant oil) or soybean oil emulsions on 26 January 1993. The spurs were cooled at $3 \mathrm{C} / \mathrm{hr}$ until $-9 \mathrm{C}$ or kept at $21 \mathrm{C}$. After treatment, the flower buds on spurs were forced at $20 \mathrm{C}$ for 11 days and then dissected. The cambium and xylem of the spurs and the interior of the flower buds were rated for damage as indicated by browning. The experiment was repeated at the silver tip stage of buds (early March) except that treated spurs were exposed to $20 \mathrm{C},-6 \mathrm{C}$, or $-9 \mathrm{C}$. Neither the oil treatments nor low temperature exposure caused visual damage to flower buds or cambium in January. However, the oil treatments damaged flower buds at the silver tip stage (March). Neither petroleum or soybean oil caused visible damage to the xylem or cambium of the spurs.

FOLIAR ELEMENTAL ANALYSIS OF SOUTHERN HIGHBUSH, RABBITEYE AND HIGHBUSH BLUEBERRIES IN THE SOUTHERN UNITED STATES

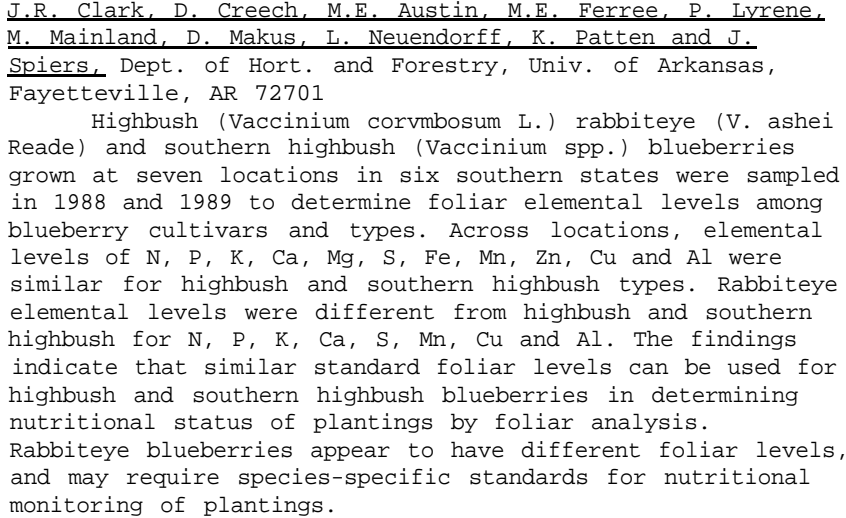

'CHANDLER' STRAWBERRY RESPONSE TO HYDROPONIC SOLUTION NITROGEN CONCENTRATION

David G. Himelrick* and W. A. Dozier. Jr., Department of Horticulture Auburn University, AL 36849-5408

'Chandler' strawberry plants were grown in a nutrient flow hydroponic systems with six solution $\mathrm{N}$ treatments $(35,70,140,210,280,350 \mathrm{ppm})$. Plant architecture was influenced by solution $N$ levels with $350 \mathrm{ppm}$ producing small dark green leaves with short petioles while $35 \mathrm{ppm}$ produced light green leaves with large leaf blades and long petioles. Other treatments were intermediate but similar to the 35 ppm with darker green foliage. The $210 \mathrm{ppm}$ treatment produced the most runners per plant while the $350 \mathrm{ppm}$ treatment produced the least. The $210 \mathrm{ppm}$ treatment produced the most crowns per plant while the $35 \mathrm{ppm}$ treatment produced the least. The highest seasonal fruit yield and largest berry size was produced in the 70 ppm treatment with the 350 treatment having the lowest yield and smallest berry size.

\section{FALL FERTILIZATION OF STRAWBERRIES WITH BORON}

Julia Whitworth* and Warren Roberts, Dept. of Horticulture \& L.A., Oklahoma State University, Wes Watkins Agri Research and Extension Center. Lane. OK 74555

In fall of 1992, 'Allstar' strawberries were planted in a greenhouse in round pots $25 \mathrm{~cm}$ wide and $22 \mathrm{~cm}$ tall Plants were grown in Peter's Professional Potting Soil that was amended to contain 0. 34, 67, or $135 \mathrm{~kg}$ nitrogen/ha, and 0 or $1.7 \mathrm{~kg}$ boron/ha. based on the surface area of the pots at media level The strawberries remained in the greenhouse throughout the 
fall, and were transferred outside for overwintering under row cover. In the spring of 1993, the plants were moved to a sheltered growing area. and the row cover was removed to allow for pollination Fruit were harvested 3 times per week and weight and number of fruit were recorded After harvest was complete. the plants were removed from the media. weighed, and analyzed for nutrient content Plants receiving boron but no nitrogen fertilizer had significantly higher boron concentration than plants receiving other combinations. Magnesium concentrations were significantly less in plants receiving the highest rates of nitrogen as compared to the other nitrogen rates Plant weight was not affected by the fertilization treatments. but fruit yield was significantly increased if $\mathrm{N}$ was added.

\section{ALLOZYME DIVERSITY IN CHESTNUT (CASTANEA} SPP.).

Hongwen Huang*. Fenny Dane and Joseph Norton, Department of Horticulture, Auburn University, Auburn, AL 36830

Allozyme genetic variability in three chestnut (Castanea) species was investigated using 19 loci from ten enzyme systems. G-tests of heterogeneity of isozymic allele distribution showed significant differences in both intraspecific and interspecific populations. $C$. mollissima was found to possess a significantly higher value of mean gene heterozygosity $(\mathrm{H}=0.3050 \pm 0.0419)$, percentage of polymorphic loci $(\mathrm{P}=84.21 \%)$ and average number of alleles per locus $(\mathrm{A}=2.05)$ than any other species in the Castanea section Eucustanon. When the genetic variability of populations of $C$. mollissimo from four regions in China was investigated, population from the Changjiang river region showed a markedly higher mean gene heterozygosity

$(\mathrm{H}=0.3480 \pm 0.0436)$ than populations from the other regions. An approximately identical genetic distance between the population from the Changiiang river region and populations from three other regions was observed, while populations from the latter regions showed almost the same genetic distance from each other.

\section{TRANSMISSION OF PLUM LEAF SCALD OR PHONY PEACH DISEASE, XYZLELLA FASTIDIOSA, WELLS, BY TWO BUDDING METHODS IN PEACH AND PLUM}

Bruce R. Abrahams* and Joseph D. Norton, Department of Horticulture, Agricultural Experiment Station, Auburn University, AL 36849-5408

The transmission of plum leaf scald or phony peach, Xylella fartidiosa, Wells is compared by the slip and chip budding with peach and plum scions on two peach rootstocks, 'Lovell' and 'Nemaguard'. ELISA was used to determine mean concentrations of the bacteria in scion leaf petioles. There was a greater level of transmission of the pathogen using chip budding over slip budding in plums but not in peach. Further analysis of slip budding showed no difference to unbudded rootstocks wheras chip budding caused a significantly higher incidence of transmission.

\section{Floriculture \& Ornamentals}

RICE HULLS AS A SOILLESS MEDIA COMPONENT FOR GREENHOUSE-GROWN PLANTS.

Shelly D. Dueitt* and Steven E. Newman, Department of Plant and Soil Sciences, Box 9555, Mississippi Agricultural and Forestry Experiment Station, Mississippi State, MS 39762

Rice hulls, a by-product of rice milling, were used at various rates in greenhouse media. The objective of this study was to determine if rice hulls can replace peat moss. Hulls, aged and fresh, were blended with vermiculite and peat moss from 0 to $50 \%$, by volume replacing peat moss. Physical and chemical properties including bulk density, total pore space, water retention,
$\mathrm{pH}$ and soluble salt concentrations were determined in the media blends. Marigolds and salvia were transplanted into $13 \mathrm{~cm}$ azalea pots containing each media. The bulk density increased with increasing levels of hulls. Total pore space of the media before planting was decreased with increasing levels of aged hulls, but no differences were detected at the termination of the study. Water retention of both fresh and aged hulls at all levels of media were equivalent to the control media. Before planting, the total soluble salts for media containing fresh hulls was greater than with aged hulls. The $\mathrm{pH}$ of the media increased with increasing levels of hulls, fresh and aged. The greatest dry weight and plant height was observed when the media contained 10 to $20 \%$ aged hulls.

FOLK RECIPES TO EXTEND THE VASE LIFE OF CUT ROSES. Lane Greer* and A. E. Einert, Department of Horticulture and Forestry, University of Arkansas, Fayetteville, AR 72701.

The frequency of purchase of cut flowers is influenced by the vase life of the stems in the consumer's home. We are attempting to find a preservative solution made of common household products to extend the vase life of cut roses. We conducted a survey of local garden club members to find what recipes they use. We compared several home recipes against three commercial preservatives and tap water. Two treatments were better than plain tap water: 1) a mixture of 1 teaspoon of vinegar, 1 aspirin tablet $(325 \mathrm{mg}$ ), and 1 tablespoon sugar in $700 \mathrm{ml}$ of water; and 2) a mixture of 1 teaspoon vinegar, 1 tablespoon sugar and 1/2 tablespoon bleach in $700 \mathrm{ml}$ of water. These treatments yielded a vase life of 9 and 8.3 days, respectively, as compared to 2.3 days for water. These treatments also proved clearly better than the three commercial preservatives tested. Changing plain water daily did not appreciably extend vase life over allowing water to remain for the entire life of the following stem. We found no relationship between water uptake and vase life; however, solution $\mathrm{pH}$ below 5.0 was necessary for extended vase life.

PROPAGATION OF AMARYLLIS BULBS BY TWIN SCALING Gerald L. Klingaman* and Troy Henderson, Department of Horticulture and Forestry, University of Arkansas, Fayetteville, AR 72701

Amaryllis bulb production is conducted in Africa, and to a lesser extent in Central America, Holland and Israel. Preliminary studies have shown bulb production is feasible in zone $6 \mathrm{~b}$ using unheated greenhouses and thermal blankets during cold periods. Spun bound polyester (Reemay) and polystyrene foam (Sentinel) provided a maximum of $9 \mathrm{C}$ protection over outside conditions. Amaryllis bulbs have been uninjured during two successive winters. A twin scale propagation experiment was conducted on the cultivar Appleblossom. Cuttings $15 \mathrm{~mm}$ wide that were placed in closed, vermiculite-filled plastic bags or uncovered, vermiculite-filled plastic trays produced 1.5 bulbs per cutting. Cuttings $7.5 \mathrm{~mm}$ wide that were placed in soil in plastic bags or open flats averaged .34 bulbs per cutting. From 75 to 80 bulblets were produced per mother bulb using wide cuttings in soil or vermiculite or narrow cuttings in vermiculite.

UNICONAZOLE AND BENZYLAMINOPURINE INFLUENCE FLOWERING AND GROWTH OF ACALYPHA HISPANIOLAE Urb. Sven E. Svenson, Fort Lauderdale Research and Education Center, University of Florida, 3205 College Avenue, Fort Lauderdale, FL 33314. Influence of uniconazole (UNI) and benzylaminopurine CBA) on flowering and growth of Acalypha hispaniolae was evaluated. Drenches of UNI at $0.02,0.1$ and $0.2 \mathrm{mg}$ ai per pot, and foliar application of 112,225 , or $450 \mathrm{mg}$ BA/liter were applied 4 weeks after potting. UNI applied at $0.02 \mathrm{mg}$ ai increased number of racemes produced 5 and 10 weeks after treatment, but did not influence shoot growth or stem length. At higher rates, UNI reduced flowering and growth. Application of $450 \mathrm{mg}$ BA/liter increased number of racemes and shoot growth 5 weeks after treatment, but not 10 weeks after treatment. The best combination of rapid shoot growth, increased number of racemes, and increased size of racemes resulted from the interactive application of 0.02 $\mathrm{mg}$ ai UN1 per pot and $450 \mathrm{mg}$ BA/liter. Better growth management might be obtained from a refinement of the concentration ranges studied. 
BIOLOGICAL CONTROL OF MEDIA-BORNE PATHOGENS OF POINSETTIAS WITH GLIOCLADIUM VIRENS.

Steven E. Newman* and Jesse R. Quarrels, Department of Plant and Soil Sciences, Box 9555, Mississippi State, MS 39762.

Jacobo Cáceres and William E. Batson, Department of Entomology and Plant Pathology, Box 9655, Mississippi State, MS 39762.

Poinsettia growers generally apply fungicide drenches to circumvent any potential problems corn soil-borne pathogens. This involves a considerable expense in chemical purchase and exposes the handler to risk. A potential biological control organism in commercial production is Gliocladium virens and is being marketed under the trade name GlioGard. This fungal organism is pathogenic towards other fungi including Rhizocotonia solani and Pythium. Two cultivars of poinsettia 'Freedom' and 'Gutbier V-14 Glory' were planted into Metro 366 medium, half colonized with $0.9 \mathrm{~kg} \cdot \mathrm{m}^{-3}$ GlioGard and half not. Half of the rooted cuttings were planted at the standard depth and half planted deep $(3 \mathrm{~cm})$. No additional fungicide treatment was made. Those plants transplanted normally without GlioGard had $70-85 \%$ survival where those treated with GlioGard had 75-95\% survival.

PINE BARK LEVELS AND PARTICLE SIZE INFLUENCE THE ACTIVITY OF PACLOBUTRAZOL AND UNICONAZOLE ON 'FREEDOM' AND 'GUTBIER' V-14 GLORY POINSETTIAS.

Jesse R Quarrels* and Steven E. Newman, Department of Plant and Soil Sciences, Box 9555, Mississippi Agricultural and Forestry Experiment Station, Mississippi State, MS 39762.

A study was conducted to determine the effects of pine bark grind size and pine bark levels on the activity of two growth regulators on poinsettia Two bark grinds ( $\leq 6 \mathrm{~mm}$ and $>10 \mathrm{~mm}$ ) were used with four media combinations within each grind: vermiculite:bark:peat moss at 2:0:3, 2:1:2, 2:2:1, and 2:3:0 (by volume). Two growth regulators, paclobutrazol and uniconazole, were applied at $0,0.125$, and $0.250 \mathrm{mg} / 15 \mathrm{~cm}$ container in 250 $\mathrm{ml}$ water. Two poinsettia cultivars, 'Freedom' and 'Gutbier V-14 Glory', were planted September 2, 1993, pinched September 16, and growth regulators applied September 30. There were five single plant replications for each treatment. Stem length and bract area were effected by bark grind, bark level, growth regulator, and growth regulator rate. Plants treated with uniconazole had the shortest stems and the least bract area. Plants grown in the smaller grind and at higher bark levels were less effected. Plants treated with paclobutrazol had longer stems than those treated with uniconazole.

\section{PHOTOSELECTIVE SHADING COMPOUNDS REGULATE GROWTH} OF HYPOESTES PHYLLOSTACHYA Bak.

Sven E. Svenson* and Diane L. Johnston, Fort Lauderdale Research and Education Center, University of Florida, 3205 College Avenue, Fort Lauderdale, FL 33314.

'Pink Splash' Hyoestes were grown in

chambers fitted with single-walled polycarbonate. Chambers were shaded with various photoselective shading compounds, using a white shading compound as a non-selective control. When grown under orange shading, plants had more shoot dry weight, greater leaf area, larger stem diameters, and were taller compared to plants shaded with white. When grown under green shading, plants had less shoot dry weight, less leaf area, smaller stem diameters, and were taller compared to plants shaded with white. Intermediate responses were recorded when plants were grown under red, blue or yellow shading. Differences in the ratio of red to far-red light among shading compounds did not provide a consistent explanation of growth responses.

\section{Postharvest \& Biotechnology} HEMICELLULOSE APPARENT MOLECULAR SIZE CHANGES
DURING SOFTENING OF PEACH FRUIT.

Supreetha Hegde* and Niels Maness, Department of Horticulture and L.A., Oklahoma State University, Stillwater, OK 74078.

Peach fruit softening appears to be associated with changes in cell wall polymers, particularly pectins and hemicelluloses. To determine changes of cell wall polymers associated with peach fruit softening, we conducted sequential extractions of pectin and hemicellulose from softening fruit. A more tightly bound hemicellulose fraction contained considerable amounts of pectin associated sugars. This fraction was separated into charged and neutral fractions, using anion exchange chromatography, and then fractionated into two apparent molecular weight classes by size exclusion chromatography. Virtually all of the charged fraction eluted in the higher apparent molecular weight fraction. The neutral sugar fraction segregated into both apparent molecular weight size classes, with a redistribution from the large to the small size class during softening. This redistribution was accompanied by changes in neutral sugar composition. A possible relationship between changes in this fraction and fruit softening will be discussed. Supported by USDA grant 92-34150-7190 and the Oklahoma Agricultural Experiment Station.

\section{IPTASE SYNTHESIS AND LIGHT MEDIATION IN TRANSGENIC} TOBACCO

Sandra L. Barbour*. Margaret J. McMahon. John J. Frett, and Dennis R. Decoteau, Horticulture Department, Clemson University. Clemson, SC 29634.

Similarities exist between the effects of phytochrome and cytokinins on plant growth and development (e.g., chloroplast development, amaranthin synthesis. seed germination, photomorphogenesis). It is unclear, however, if and how these two systems interact.

As a beginning step to determine cytokinin-phytochrome interactions, we developed a strategy utilizing ipt -transgenic tobacco in phytochrome/light treatment investigations. The sour-cc of the ipt gene was Agrobacterium tumefaciens Ti plasmid 15955. This gene encodes for isopentenyl transferase which is an enzyme active in cytokinin biosynthesis.

Ipt -transgenic tobacco cultures (grown on MS medium supplemented with kanamycin but no plant growth regulators) were treated with end-ofday red or far-red light for 15 minutes. After 30 days of treatment, the plant tissue was harvested and either homogenized for SDS-PAGE or fixed for transmission electron microscopic analysis.

Results from immuno-gold labelling using polyclonal antibodies specific to iptase will he used to Indicate the influence of phytochrome on cytokinin activity. Also, structural changes at the ultra-cellular level will be determined.

STORAGE LIFE AND QUALITY OF BLACKBERRY FRUIT WHEN HELD AT TEMPERATURES GREATER THAN $1 \mathrm{C}$ P. Perkins-Veazie ${ }^{1}$, J.K. Collins ${ }^{1}$, and J.R. Clark ${ }^{2} *$, ${ }^{1}$ U S D A ARS, South Central Agri. Research Lab., Lane, OK 74555; Dept. Hort. and Forestry, Univ. of Arkansas, Fayetteville, AR 72701 The storage life of blackberry fruit is generally ' 2 to 3 days when stored at $1 \mathrm{C}$. This study was done to determine the maximum storage life among erect blackberry cultivars, and to determine storage temperature effects on storage life Shiny black fruit from 'Navaho', 'Arapaho', and 'Shawnee' cultivars were stored at $2 \mathrm{C}, 5 \mathrm{C}$, or $10 \mathrm{C}$ for 20,14 , and 7 days, respectively. At any temperature. only $10-20 \%$ of 'Navaho' fruit had decay, while 30-50\% of 'Arapaho' and 40$70 \%$ of 'Shawnee' fruit had decay. Weight loss was 3-5\% depending on temperature and was not different among cultivars. Soluble solids concentration did not change during storage but titratable acidity decreased in all cultivars for fruit held at all temperatures. Anthocyanin content increased during storage in 'Shawnee' and 'Navaho' but not in 'Arapaho' fruit. Results indicate that 'Navaho' fruit have a longer shelflife than other blackberry cultivars. 
ORGANOLEPTIC QUALITY OF MINIMALLY PROCESSED SUPERSWEET

CORN

J.K. Collins ${ }^{1}$, P. Perkins-Veazie ${ }^{1}$, E.V. Wann ${ }^{1}$ and $\mathrm{N}$

Maness ${ }^{2} \star,{ }^{1} U S D A$, ARS, South Central Agricultural

Laboratory, Lane, Oklahoma 74555, '2Department of

Horticulture, Oklahoma State University, Stillwater, Oklahoma 74078 .

Supersweet corn with the shrunken-2 gene $\left(\mathrm{sh}^{2}\right)$ has shown good quality after frozen storage. A study was undertaken to further evaluate the quality of supersweet corn (CV Florida Staysweet) unblanched or blanched then

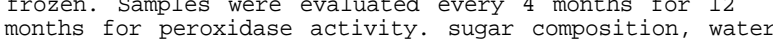
months for peroxidase activity. sugar composition,
soluble polysaccharides and organoleptic qualities.

Peroxidese activity changed in unblanched corn at each Peroxidese activity changed in unblanched corn at each sampling date, which was consistently higher than in blanched corn. Sucrose and total sugars declined during storage. Sucrose was highest in blenched samples and reducing sugars were highest in unblanched samples. WSP content was low in all samples, but lower in blenched compared to unblanched samples. Taste panelists discerned differences between blanched and unblanched corn at 8 months when blanched samples were rated as more yellow. than unblanched. However, no differences were found for taste between blanched and unblanched samples for taste at 12 months. These results indicate that $\mathrm{sh}_{2}$ sweetcorn maintained good eating quality for 12 months of frozen storage with or without blanching.

RELATIONSHIP BETWEEN DESICCATION AND CHILLING INJURY IN CUCUMBER FRUIT A.C. Purvis, Department of Horticulture, University of Georgia, Coastal Plain Experiment Station, Tifton, GA 31793

Chilling injury (CI) is an important postharvest physiological problem that limits the storage life of many warm-season fruits and vegetables. Variability exists among cultivars and CI appears to be related to moisture loss during low temperature storage. The relationship between moisture loss and CI was examined using fruit from 64 PI lines of field-grown Cucumis sativus. A wide variation existed among the lines in the sensitivity of their fruit to low temperatures. Fruit from 8 of the lines developed severe symptoms of CI after 5 days at $5{ }^{\circ} \mathrm{C}$ and fruit from 21 lines developed no injury symptoms. CI symptoms developing during 2 and 4 days of storage at $15^{\circ} \mathrm{C}$ were highly significantly correlated with weight loss during the 5 days of storage at $5^{\circ} \mathrm{C}$. Crosses were made between chilling-sensitive and chilling-resistant lines. CI symptoms of the $F_{1}$ fruit were highly significantly correlated with weight loss during the 5 days of storage at $5^{\circ} \mathrm{C}$.

\section{MOLECULAR MARKERS FOR APOMIXIS IN Pennisetum}

Peggy Ozias-Akins*', Edward L. Lubbers', and Wayne W. Hannna², 'Department of Horticulture and ZUSDA-ARS, University of Georgia Coastal Plain Experiment Station, Tifton, GA 31793-0748

Apomixis is asexual reproduction through seed. Apomixis in the genus Pennisetum is of the gametophytic (aposporous) type. Genes for apomixis have been transferred from a wild apomictic species $(P$. squamulatum) to pearl millet (P. glaucum) by conventional breeding to produce an obligately apomictic backcross $3\left(\mathrm{BC}_{3}\right)$ plant (Dujardin and Hanna, 1989, J. Genet. Breed. 43:145). Molecular markers based on restriction fragment length polymorphisms and random amplified polymorphic DNAs were identified in $\mathrm{BC}_{3}$ that were shared only with the apomictic parent. Segregation of these informative markers in a $\mathrm{BC}_{4}$ population indicated that three linkage groups from $P$. squamulatum were present in $\mathrm{BC}_{3}$ and that minimal recombination between these alien chromosomes and those of the recurrent parent occurred. Transmission of only one of the linkage groups was required for transfer of apomixis Recombination is essential for genetic mapping, thus we are beginning to map the informative molecular markers in an $\mathrm{F}$, interspecific cross between pearl millet and $P$. squamulatum, a population that segregates for apomictic and sexual reproduction.

\section{PREDICTION OF STARCH AND OTHER SOLIDS CONTENT IN SWEETPOTATOES} BY VISCOSITY

Juan L. Silva* and Kednal Alexis, Department of Food Science and Technology, Mississippi State University, Mississippi state, MS 39762 .

$$
\text { Models for prediction of starch, alcohol-insoluble }
$$
solids (AIS) and glucose were developed by measuring the solids (AIS) and glucose were developed by measuring the
viscosity of freeze-dried sweetpotato [Ipomoea batatas (L.) viscosity of freeze-dried sweetpotato [Ipomoea batatas (L.)
Lam] flour. Green (processed within $24 \mathrm{~h}$ ) and cured. Jewel Lam] flour. Green (processed within $24 \mathrm{~h}$ ) and cured. Jewel and Beauregard roots-were cooked, peeled, pureed and freezedried. Viscosity of the flour was measured with a Brabender
Viscoamylograph and a Brookfield Viscosimeter. Total solids, Viscoamylograph and a Brookfield Viscosimeter. Total solids, There was a strong correlation $\left(R^{2}=0.99\right)$ between Brookfield and Brabender viscosity. Results showed significant correlations between Brookfield apparent viscosity or Brabender viscosity units at the gelatinization stage and starch $\left(R^{2}=0.82\right.$ and 0.81$)$, AIS $\left(R^{2}=0 . S 7\right.$ and 0.81$)$, and glucose $\left(\mathrm{R}^{2}=0.87\right.$ and 0.86$)$ content. Apparent viscosity of flour from green roots increased through gelatinization and upon cooling, but that from cured roots remained constant throughout.

\section{Posters}

\section{APPLIED USE OF MIXED MODEL VS FIXED MODEL ANALYSIS IN FIELD RESEARCH}

William Terry Kelley, Rural Development Center, P.O. Box 1209, Tifton, GA 31793. Statistical analysis of agricultural research has traditionally been via the use of fixed model methods. However, recent advances in statistical software have made analysts through random or mixed model methods more practical. Errant or inappropriate use of statistical programs to analyze data has been a recurring problem in the reporting of agricultural research findings. Often variables are all considered to be fixed in order to facilitate analysis, when in reality some variables in field research are nearly always random. Proper selection of error terms and calculation of standard errors are also frequently done incorrectly when statistical analysts packages are not used correctly. Unbalanced data is also quite normal in field research due to unforseen circumstances that result in lost information. Most of these situations can be more early handled with a mixed model approach. In this work, a broccoli field trial involving tillage and planting dates was analyzed using the General Smear Models procedure in SAS and the General Elmer Mixed Models Procedure in GLMM. Comparison of the analyses revealed that conclusions would differ somewhat with balanced data and even more with unbalanced data. Since variance components from all random effects are used to calculate standard errors in GLMM, standard errors in the mixed model were larger, but likely more accurate Inference space was also broader and allowed prediction space to include the entire population of experimental units which were sampled in the experiment. The mixed model procedure was more efficient and thus more sensitive to differences in treatments.

EXTRACTION AND IDENTIFICATION OF MANNITOL FROM ANTIRRHINUM MAJUS L. LEAVES

Ricardo Campos*, Ma. Estela Peralta, Daniel W. Bearden and William B. *Miller, Department of Horticulture (R.C., M.E.P., W.B.M.), and Chemistry (D.W.B.), Clemson University, Clemson, SC 29634.

Soluble carbohydrate extracts from Antirrhinum majus L. leaves were fractionated by ion exchange chromatography. Putative mannitol was tentatively identified by retention behavior on two high performance liquid chromatography columns. Mannitol was confirmed using ${ }^{1} \mathrm{H}$ and $13 \mathrm{C}$ nuclear magnetic resonance (NMR), and by gas chromatography (GC) and mass spectroscopy (MS). The melting point of authentic and putative mannitol, and a $1: 1 \mathrm{mix}$ was from 164 to $166^{\circ} \mathrm{C}$. Using the EDTA-phloem exudate technique, mannitol was detected in phloem tissue associated with mature flowers, flower buds, and mature leaves, suggesting that mannitol is translocated in Antirrhinum.

\section{GROWTH REGULATOR EFFECT ON PIGEONPEA (CAJANUS CAJAN) DEVELOPMENT}

Lurline Marsh, Dyremple Marsh and Brian Cooper, Cooperative Research, Lincoln University, Jefferson City, MO 65102-0029 and Caribbean Agricultural Research and Development Institute, St. Johns, Antigua.

The influence of benzyladenine (BA) and ethrel on vegetative and reproductive characteristics of 2 pigeonpea genotypes was evaluated in field and greenhouse study. Plants sprayed with benzyladenine or ethrel at 400 or $800 \mathrm{ppm}$ levels at both the vegetative and flowering stages tended to be smaller, had more floral abscissions and produced more pods than those sprayed only at the flowering stage. Increased chemical concentration decreased plant size. Plants treated with BA produced several curved distorted leaflets. None of the applications in the field study significantly improved pod set over the $23 \%$ recorded for the controls. 
INHERITANCE OF ANTHOCYANIN DEFICIENCY IN DEWBERRY (RUBUS TRIVIALIS

Creighton Gupton, USDA-ARS Small Fruit Research Station, Poplarville, MS 39470

Anthocyanin deficient dewberry (Rubus trivialis Michx.) clones with translucent ripe fruit and green canes were studied to determine their possible utilization as a source of marker genes for blackberries. Albino dewberries from two locations designated Bonnette (BON and Harriel $(\mathrm{H})$ were crossed with each other and with normal dewberry (DB). $F_{1}$ plants were testcrossed. DB X $\mathrm{H}$ produced 62 plants all of which had red canes. BON X DB produced 59 plants all of which had red canes. BON X H produced nine plants all of which had green canes. The segregation ratio of each testcross supported the hypothesis that anthocyanin deficiency in dewberry is controlled by a single recessive gene. A recessive allele $t$ known to cause a very low concentration of anthocyanin, giving fruit with yellow color and stems with non-pigmented spines, is probably responsible for the mutant trait. Its simple inheritance provides potential for anthocyanin deficiency to be used as a marker gene.

REPLACEMENT-PLANTED WATERMELON HILLS

Melvin R. Hall, Department of Horticulture, University of Georgia, Coastal Plain Experiment Station, P.O. Box 748, Tifton, GA 317930748

Primary vine lengths of 'Crimson Sweet' watermelon directseeded on 25 March and 24 April 1992 were 62 and $58 \mathrm{~cm}$ within 7 and 5 weeks, respectively. Lengths of replacement vines direct-seeded on 20 April and 14 May in the respective plantings were 6\% and 5\%) while transplants were $46 \%$ and $52 \%$ of these lengths. Total number of marketable fruit and total tonnage yield from late March plantings (suboptimal soil temperatures) in 1992 and 1993 were enhanced when missing hills were replanted either by direct seeding or transplanting. However, these measurements from late April plantings (optimal soil temperatures) were not influenced by missing hills or replanting methods in either year. Distribution of fruit sizes varied for the two years and there was no consistent pattern to indicate how fruit size influenced total number of marketable fruit or total marketable tonnage yield.

COTTON GIN TRASH COMPOST AS A CONSTITUENT OF VEGETABLE TRANSPLANT MEDIA

Blair Buckley*, and Katharine C. Pee, Calhoun Research Station, Louisiana Agricultural Experiment Station, LSU Agricultural Center, P.O. Box 539, Calhoun, LA 71225

Media contaming cotton gin trash compost, pear. and perlite were evaluated for production of bell pepper, broccoli, and cabbage transplants. Media treatments were 0:5:5; 1:4:5; 2:4:5; 3:2:5; 4:1:5; and 5:0:5 compost, peat, perlite, respectively $(\mathrm{v} / \mathrm{v})$. Separate tests were conducted for each crop. 'Jupiter' pepper, 'Packman' broccoli, and 'Grand Slam' cabbage were seeded in 96-cell plastic trays (cell volume $=39 \mathrm{~cm}^{3}$ ). Plant height, stem diameter, and shoot and root dry weight were recorded five weeks after seeding bell pepper and broccoil, and six weeks after seeding cabbage. Pepper, broccoli, and cabbage transplants grown in media containing cotton gin trash compost had greater plant height, stem diameter, and shoot and root dry weight than transplants grown in the medium without compost as a component. The growth response to percent of compost was primarily linear.

DETERMINING MATURITY INDICES OF ROMANO BUSH BEANS Charles A. Mullins and Richard A. Straw, Department of Plant and Soil Science, University of Tennessee, Crossville, TN 38555

Harvest maturity of round-podded snap beans is based on pod diameter. Flat-podded cultivars such as 'Roma II' require a different maturity index. Pod fiber and seed development are two leading indicators of maturity and pod quality and both are highly dependent upon environmental conditions. Experiments were conducted at the Plateau Experiment Station at Crossville in 1993 to evaluate changes in pod characteristics as the crop matured. The objectives were to evaluate indices for field use to determine optimum maturity of 'Roma II' bush beans for processing usage. Harvests were made at two day intervals starting before optimum maturity and continuing until a decline in maximum yields had occurred. Seed length of $100 \mathrm{~mm}$ for 10 seeds extracted from the most mature pods appeared to be an acceptable guide for harvest maturity to assure maximum yields and excellent pod quality.
PERENNIAL LEGUME GROUND COVERS INCREASE BENEFICIAL ARTHROPODS AND SUPPLY NITROGEN IN PECAN ORCHARDS A. Shiferaw*, M.W. Smith. R.D. Eikenbary, Don C. Arnold, Oklahoma State University, Stillwater, OK 74078

Perennial legumes ground covers were evaluated in pecan (Carya illinoinensis) orchards to supply nitrogen and increase beneficial arthropods. Ground covers were 'Kenland' red clover (Trifolium pratense), 'Louisiana S-1' white clover (Trifolium repens), a mixture of these two legumes, or bermuda grass (Cynodon dactylon), each in 5 ha plots. Nitrogen was applied at $0-200 \mathrm{~kg} \cdot \mathrm{ha}^{-1} \mathrm{~N}$ in $50 \mathrm{~kg}$ intervals to bermuda grass plots, and was omitted on the legumes. Aphids feeding on the legumes attracted lady beetles; however, lady beetle populations in the tree canopies were not affected by ground cover treatment. The most abundant lady beetle species in legumes were Coleomegilla maculata lengi (77\%) and Coccinella septempunctata (13\%); whereas, dominant species in tree canopies were Coleomegilla maculata lengi (33\%). Olla v-nigrum (20\%). Cycloneda munda (18\%) and Coccinella septempunctata (15\%). Several other beneficial arthropods were sampled in legumes and tree canopies. Aphid populations feeding on pecans were low (peak population $\approx 2$ aphids/leaf), and not affected by ground cover treatment. Legumes supplied the equivalent of applying $68-156 \mathrm{~kg} \cdot \mathrm{ha}^{-1} \mathrm{~N}$.

BETTERSNAP: A NEW, EDIBLE PODDED SOUTHERNPEA R. L. Fery and P. D. Dukes*, U.S. Vegetable Laboratory, ARS, USDA, 2875 Savannah Highway, Charleston, SC 29414 Bettersnap southernpea (Vigna unguiculata) was developed as a replacement for the popular cultivar Snapea. The new cultivar is well adapted for production throughout the southern United States where it can be expected to produce excellent yields of edible pods or snaps. Bettersnap is resistant to root knot, a severe root disease incited by several species of the root-knot nematode (Meloidogyne spp.), and blackeye cowpea mosaic virus, the major pathogen of southernpea in the United States. Observations of natural epiphytotics indicate that the cultivar is also resistant to scab (Cladosporium vignae) and cercospora leaf spot (Cercospora cruenta). The new cultivar has the same maturity and high yield potential as Snapea. Bettersnap is recommended for use as a home garden cultivar for spring, mid-season, and fall plantings. It is particularly recommended for trial as a commercial processing cultivar for the production of the immature green pods used for the "snap" component of the popular mixed packs of fresh peas and green snaps.

MECHANICAL IMPULSE RESPONSE AS A MEASURE OF TOMATO FRUIT MATURITY.

${ }^{1} D$. Chrz*, $N$. Maness, ${ }^{2} D$. Chen and ${ }^{2} M$. Stone. Departments of ${ }^{1}$ Horticulture and L.A. and ${ }^{2}$ Biosystems and Agricultural Engineering, Oklahoma State University, Stillwater, OK 74078

A mechanical impulse system for determining tomato fruit maturity and size was tested, for development of a rapid, nondestructive fruit testing instrument. Fruit were grouped into various maturity categories, ranging from immature green to red, and impulse spectra were obtained at a site over the locule at marked locations. Resistance to puncture was measured on the locular side of the pericarp wall at the same locations. A sonic resonant frequency band was weakly correlated with fruit maturity category. Stronger correlations existed with pericarp puncture resistance and fruit weight. A description of essential components and utilization of the instrument for fruit firmness determination will be presented. Supported by OCAST (Oklahoma Center for the Advancement of Science and Technology) grant AR2-069, USDA grant 92-34150-7190 and the Oklahoma Agricultural Experiment Station.

\section{THE EFECTS OF LEONARDITE ON GROWTH OF TOMATO SEEDLINGS}

A.J. Pertuit, Jr., Department of Horticulture, Clemson University, Clemson, SC 29634-0375

Lycopersicon Lycopersicum 'Mountain Pride' seedlings were greenhouse grown for 8 weeks in pots of Congaree silt loam amended with $1 / 8$ volume leonardite. They received the recommended rate or half the recommended rate of 5-10-10 granular fertilizer (surface applied) with urea or ammonium sulphate as $\mathrm{N}$ sources. Leonardite enhanced plant growth (plant height, fresh and dry weights, stem diameter, and leaf area) only when utilized with a complete fertilizer, regardless of the $\mathrm{N}$ source; however, it was more effective with ammonium sulphate than with urea. With ammonium sulphate, the amount of $\mathrm{N}$ applied could be halfed if leonardite were added, producing about the same positive results achieved with urea at the full recommended $\mathrm{N}$ rate hut without leonardite added. 
WINTER COVER CROPS AND NITROGEN FERTILIZER EFFECTS ON TOMATO AND BEAN PRODUCTION: A THREE YEAR SUMMARY Kathy H. Brock*. Heather A. Hatt and Dennis R. Decoteu Dept. of Horticulture, Poole Agriculture Center, Box 340375, Clemson University, Clemson, SC 29634-0375.

Winter cover crops (wheat or rye and crimson clover) in combination with three levels of nitrogen fertilizer $(0,60,120 \mathrm{~kg} / \mathrm{ha})$ were evaluated as to their influence on bean and tomato production (fruit yield, disease and insect injury on fruit) over a three year period (1991-1993). A split plot design was used with the cover crop as the main treatment and nitrogen rate as the split treatment. Results indicate that total marketable and cull yields for bean increased significantly in 1992 but decreased again in 1993. Tomato yields were significantly greater in 1991 than in 1992 and 1993 for both early and total marketable yields while early cull yield increased each year and total cull yield was highest in 1993. Cover crop had an effect on non-marketable tomato fruit. There was a higher incidence of cracked and insect damaged tomato fruit in association with clover or fallow treatment. Marketable yields responded in a quadratic manner while the number of cull fruit increased linearly for both bean and tomato as nitrogen rate increased. The incidence of diseased bean pods increased linearly as nitrogen rate increased. Catfaced tomato fruit responded in a quadratic manner and cracked tomato fruit increased linearly as nitrogen increased. Results from the three year evaluation do not indicate an influence of cover crop on marketable yields of bean and tomato.

MINERAL UPTAKE IN MUSCADINE CULTIVARS

James M. Spiers*, USDA-ARS Small Fruit Research Station, Poplarville, MS 39470

Five muscadine grape (Vitis rotundifolia) cultivars ('Carlos', 'Doreen'. 'Magnolia', 'Pineapple' and 'Summit') were grown in sand-peat-pine bark ( $1: 1: 1$ ) medium and fertilized with a complete macro- and micronutrient solution plus added $\mathrm{Na}$. Plant growth plus mineral uptake in 4 plant parts (leaves, terminal stems, basal stems and roots) were measured. Top growth (leaves plus stems) was highest in 'Pineapple' and lowest in 'Doreen'. Root growth was higher in 'Carlos' and 'Doreen' and lowest in 'Magnolia'. Plant part $x$ cultivar interactions were significant for elemental $\mathrm{Ca}, \mathrm{Mg}, \mathrm{Na}, \mathrm{Fe}, \mathrm{Zn}, \mathrm{Cu}$, and $\mathrm{Mn}$. Iron tended to be concentrated in the roots and leaves. Leaves and upper stems contained more $K$ than the lower stems and roots and $K$ concentrations were higher in 'Carlos' and 'Magnolia' than the other cultivars. Sodium content tended to be higher in the leaves than in the other plant parts. Little differences were present in Na uptake by the 5 cultivars.

FOLIAR TOTAL NONSTRUCTURAL CARBOHYDRATES IN APPLE CULTIVAR/ROOTSTOCK COMBINATIONS

Frank B. Matta*, Crofton Sloan and Shakeel Khan, Plant and Soil Sciences Department, Mississippi State University, Mississippi State, MS 39762 Apple leaves from current seasons' growth at mid-season (July) and during dormancy (December) were used to determine the influence of various apple scion/rootstock combination on total non-structural carbohydrates (TNC). 'Empire' and 'Royal Gala' had higher foliar TNC at mid-season compared to 'Ultra Gold' on MM.106. 'Empire' had higher foliar TNC on Mark than on MM.111, M.7A and M.26. 'Blushing Golden' had higher foliar TNC on MM.111 than on the remaining rootstock\% There was no significant interaction between cultivar and rootstock. Foliar TNC During Dormancy: 'Blushing Golden' had the highest and lowest foliar TNC on MM.111 and M.7A, respectively. Cultivar differences did not exist with any rootstock. Foliar TNC results of this study indicated that there was a higher foliar TNC percentage in leaves at mid-season compared to leaves during dormancy. Data indicated cultivar influences on foliar TNC only at the mid-season. It seems that cultivar differences in TNC might be due to an increase in TNC formation, which during dormancy was stabilized. Rootstock influenced foliar TNC both at mid-season and during dormancy.
TOMATO TRANSPLANT PRODUCTION USING THE FLOAT TRAY SYSTEM

Jim E. Wyatt*. Marla C. Akridse and Douglas W. Hamilton, University of Tennessee, West Tennessee Experiment Station, 605 Airways Boulevard, Jackson, TN 38301

Studies were conducted in plastic foam trays in float tanks to investigate effects of aeration of the nutrient solution, tray manament after seeding and addition of $\mathrm{KNO}_{3}$ fertilizer to the substrate media on tomato transplant growth. Aeration of the nutrient solution had no effect on rate of tomato seedling emergence or growth, even though dissolved $\mathrm{O}$, was higher in aerated tanks than in non-aerated tanks. Placing trays in the tanks immediately after seeding caused faster seedling emergence than either delaying placement in the tanks or stacking trays until emergence began. $\mathrm{KNO}_{3}$ at $20 \mathrm{~g} \cdot \mathrm{kg}$ dry Pro-Mix" media resulted in delayed initial emergence but no differences were found 7 days after planting. Initial tray treatments or addition of $\mathrm{KNO}_{3}$ to the media had no effects on final tomato transplant size.

INTERCROPPING STRAWBERRIES WITH MARIGOLDS, PARSLEY, AND DILL

Julia Whitworth, Dept of Horticulture \& L A., Oklahoma State University, Wes Watkins Agri. Research and Extension Center, Lane, OK 74555

In February 1992. 'Allstar' strawberry plants were planted in 16 plots Each plot was three rows wide and $5 \mathrm{~m}$ long The rows were spaced $1 \mathrm{~m}$ apart, and wheat straw mulch was spread between them. In June, marigold, parsley. or dill plants were set through the straw on either side of the center row of each plot The control plots had no plants set between the strawberry rows The marigolds and parsley grew into full size plants. but the dill bolted and did not produce much plant mass Plots with marigolds and parsley in them appeared to have less weeds and strawberry daughter plants growing between the rows. although weeds were still a problem in the strawberry rows. No significant arthropod infestations occurred in any of the plots The marigolds made their plots especially attractive during the growing season, and the parsley remained green during the winter when the strawberry plants turned red and went dormant The next spring. the strawberry fruit were harvested The marigolds and dill were trampled by the pickers There were no significant differences in strawberry yield or fruit quality among the four treatments.

CHINESE CABBAGE PERFORMANCE

David L. Coffey, Department of Plant and Soil Science, University of Tennessee, Knoxville, TN 37901-1071

Results from a three-year cultivar evaluation study indicate that Chinese cabbage production is feasible in Tennessee, but may require special attention to bacterial disease control. Individual head weight and projected yields of both the heading (pe tsai) and the nonheading (pak choy) forms compared well to those reported from areas where it is adapted and widely grown. Additional research is needed to identify appropriate planting dates and slow-bolting cultivars, especially for spring production. The ability to achieve predictable and profitable spring and fall production of this specialty crop is essential for establishing markets and promoting Chinese cabbage as a reliable crop that can be incorporated readily into vegetable production systems. 